\title{
Durable Late Blight Resistance in Potato Through Dynamic Varieties Obtained by Cisgenesis: Scientific and Societal Advances in the DuRPh Project
}

\author{
A. J. Haverkort ${ }^{1}$ - P. M. Boonekamp ${ }^{1}$ - R. Hutten ${ }^{1}$ • \\ E. Jacobsen ${ }^{1}$ - L. A. P. $\operatorname{Lotz}^{1}$ • G. J. T. Kessel ${ }^{1}$. \\ J. H. $\operatorname{Vossen}^{1}$ - R. G. F. Visser ${ }^{1}$
}

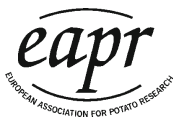

Received: 15 July 2015 / Accepted: 15 December 2015 /

Published online: 25 January 2016

(C) European Association for Potato Research 2016

\begin{abstract}
From 2006 through 2015, a research project on Durable Resistance in potato against Phytophthora (DuRPh) was carried out at Wageningen University and Research Centre. Its objective was to develop a proof of principle for durable resistance against late blight by cisgenesis. This public-funded project aimed at stimulating research on genetic modification and public debate on innovative genetic techniques. It was decided to clone and transfer late blight resistance $(R)$ genes of crossable wild potato species (cisgenes) by Agrobacterium tumefaciens-mediated transformation without non-potato genes. A stack of multiple $R$ genes were planned to be inserted into established varieties, thereby creating a dynamic variety in which the composition of the stacks may vary over space and time. Cisgenic plants were selected based on the expression of all inserted $R$ genes and trueness-to-type. Within the project, $13 R$ genes from wild potato species were genetically mapped and three of them were cloned. Four varieties were transformed with one to three $R$ genes. This was initially done using kanamycin resistance provided by a selectable marker gene of synthetic origin in order to quickly test the performance and stability of the introduced $R$ genes and stacked $R$ gene combinations. Once the functioning thereof was confirmed, marker-free transformations were conducted; thus, true cisgenic events were selected. The results about the different $R$ genes, their chromosomal location, their specificity, the background dependence, the maximum size of a stack, its regeneration time and associated somaclonal variation frequency and its stability were studied. After selection and characterisation in the laboratory, the best cisgenic events were assessed in field trials for late blight resistance. This showed that inserted $R$ genes were capable of turning a susceptible
\end{abstract}

J. H. Vossen

jack.vossen@wur.nl

1 Wageningen University and Research Centre, P.O. Box 16, 6700 AA Wageningen, The Netherlands 
variety into a resistant one. Maximising longevity of the resistance was assured through resistance management research. It was shown that stacking of multiple $R$ genes and monitoring how to deploy these stacks spatially and temporally could reduce fungicide use by over $80 \%$. Communications through media and field demonstrations were manifold to allow public and policymakers to decide if cisgenesis is an acceptable tool to make potato farming more sustainable. Future deployment of the DuRPh strategy will depend largely on its status as a genetically modified crop or its exemption thereof. Worldwide near eradication of late blight would increase global annual potato production by close to 80 million tons, thereby contributing considerably to the needed additional global future food supply.

Keywords Cisgenesis - Conventional breeding · Food security · Multi-gene resistance True-to-type

\section{Introduction}

In 2005, an interdepartmental group of policymakers of the Netherlands government came to Wageningen University and Research Centre to commission a research project on genetic modification in crops. At that time, there was a public tendency against the use of such techniques, fueled by non-governmental organisations concerned about possible adverse effects on humans, environment and society. In 2005, globally, 90 million ha of genetically modified crops were planted of which hardly any in Europe and none in the Netherlands. In 2014, this global area had more than doubled (James 2014). The Netherlands government wanted to invest in a genetic modification (GM) research and development project in order to remain scientifically competitive while promoting a more sustainable agriculture. This effort needed to be carried out with public funds because companies did not invest in view of consumer's reluctance and high costs associated with regulatory requirement of GM crops. Hence, it was proposed to set up a research project on genetic modification. A vision on biotech and innovation, expressed by a joint project group of several Netherlands ministerial departments, identified important stumbling blocks for the acceptance of genetically modified crops. These were that citizens are informed too little or unilaterally; that the government, science and industry were insufficiently transparent; and that these parties offered citizens too few possibilities to learn and comment when it comes to research and development with respect to GM crops.

It was decided to choose a favourable case that would improve the low societal acceptance of GM crops. Potato was chosen, it being the most important arable crop in the country with about 7 million tons produced of which over 1 million tons of seed potatoes of which $70 \%$ is exported. Especially potato late blight, caused by the oomycete Phytophthora infestans, is responsible for the use of more than $50 \%$ of all pesticides in the Netherlands. Beside the negative impact on the environment, the dependence on chemical pesticides represents high costs. The farm gate price of the total annual production in the Netherlands exceeds $€ 700$ million, and losses due to prevention and control of this disease are over $€ 100$ million/year. Losses on the 30 million-ha global potato area that yield over 400 million tons of potato are estimated at 7 billion euros (Haverkort et al. 2008). The control of late blight accounts for more 
than $10 \%$ of the $\mathrm{CO}_{2}$ needed for potato production (Haverkort and Hillier 2011). Prior to the Durable Resistance in potato against Phytophthora (DuRPh) project, two substantial and cooperating research programmes were already ongoing: the 'Masterplan Phytophthora' (Dutch Arable Board) and the 'Umbrella Plan Phytophthora' (Wageningen UR). Both aimed at significantly reducing the environmental impact of potato late blight control. As a result of these programmes, the environmental impact of P. infestans control could be reduced by an estimated 95\% in 2010 as compared to 1998 (Anonymus 2013). However, the dependence on fungicides was not significantly reduced and it became clear that durable host resistance is the key ingredient for sustainable control of late blight in practice. The Umbrella Plan Phytophthora started to uncover the potential of genetic resistance sources in the Solanum germplasm (Vleeshouwers et al. 2011). Introgression of the novel resistance $(R)$ genes through classical breeding started, but the development of durably resistant varieties takes decades. Introgression of $R$ genes other than from Solanum demissum started already in 1959 when a cross was made between Solanum bulbocastanum (B, 2×) containing Rpi-blb2 and Solanum acaule (A, 4×) resulting in AB $(3 \times)$ that, in 1965 after polyploidisation to the hexaploid level, was crossed with Solanum phureja (P, $2 \times$ ) resulting in ABP (4×). These bridge crosses were needed to finally be able to cross with Solanum tuberosum yielding ABPT $(4 \times)$ material that, through three successive backcrosses to $S$. tuberosum, finally yielded the late blight resistant varieties Bionica (2008) and Toluca (2006). So, it took almost half a century to introgress this single $R$ gene using conventional plant breeding techniques. Nowadays, introgression breeding in $S$. tuberosum using direct crosses to wild Solanum species, assisted by molecular markers and other breeding tools, can be reduced significantly. It remains, however, a timeconsuming procedure especially when $R$ gene stacks are required to establish durable resistance. This tardy breeding process results in an uneven arms race between potato and $P$. infestans that is notorious for its highly flexible genome, causing rapid adaptation to host resistance. The use of GM techniques to rapidly add multiple $R$ genes into established varieties may balance this arms race in favour of potato. The production and release of such dynamic varieties was expected to be achieved within a few years. It was expected that with the use of these resistant varieties, at least $80 \%$ reduction in the use of fungicides could be realised, equivalent to a $40 \%$ reduction of all used chemicals in agriculture and horticulture in the Netherlands (Haverkort et al. 2009). It was in this perspective that the DuRPh project was coined and received a $€ 10$ million grant for the duration of 10 years, 2006-2015.

For the case to be most favourable, it was decided that the project would use only $R$ genes of wild Solanum species that are crossable with cultivated potato varieties $(S$. tuberosum). Such products are referred to as cisgenic. The final product would not contain the selectable marker gene conferring resistance to antibiotics or herbicides as usually used in transgenesis. The new variety would only contain genes belonging to the potato gene pool referred to as cisgenes (Schouten et al. 2006). Routinely used procedures for genetic modification have been used: cloning of $R$ genes in the bacterium Escherichia coli and transforming it to a potato variety with the aid of another bacterium Agrobacterium tumefaciens. All late blight $R$ genes identified so far encoded nucleotide-binding leucine-rich repeat region (NB-LRR) proteins. These proteins are located intracellular and serve as specific receptors for P. infestans effector proteins (also known as avirulence (Avr) proteins) that are deposited in the host 
cytoplasm. $P$. infestans has shown to be able to rapidly break resistance based on a single $R$ gene. This is because mutations that avoid the recognition of the $P$. infestans effector can easily happen in the natural diversity or by genetic systems of the pathogen. To impose incremental hurdles for the pathogen, a stack with several $R$ genes needed to be transferred. Through virulence monitoring in the field, the efficacy of the $R$ gene stack is followed to ascertain long-term durability of the resistance. Only established varieties would be transformed as these have proven their value in the marketplace. The new cisgenic genotype had to be 'true-to-type', meaning it is indistinguishable from the variety it is derived from with the exception of the presence of the $R$ genes and late blight resistance. This cisgenic breeding approach has been extensively reviewed recently (Jo et al. 2016).

Within the project, five teams simultaneously or successively worked on (1) tracking and cloning of $R$ genes in wild potato species (sub-project cloning); (2) the composition of $R$ gene constructs and their transfer to varieties (sub-project transformation); (3) selection in a lab, greenhouse and field to determine the level of expression, late blight resistance and true-to-type (sub-project selection); (4) resistance management research in field trials, monitoring plots and using epidemiological models to steer and monitor resistance (sub-project resistance management); and (5) communication of the approach and results actively to all parties of interest (sub-project communication). The research generated intellectual property that, in the future, can be exploited by Wageningen UR and companies. This will hopefully enable the university to prolong this research in the future. For developing countries, a humanitarian use licence of the project technology was contemplated.

The objective of the DuRPh project was the development of a proof of concept that existing potato varieties could be made durably resistant to late blight with stacked $R$ genes combined with adequate resistance management. The objectives of this paper are to highlight the approach and to present an anthology of the major scientific results of the DuRPh project, the ongoing activities to implement the approach and the debate in the community and to illustrate the potential impact on global food security. The approaches and results of the various sub-projects of the DuRPh project are given in the next sections.

\section{Sub-project 1: Cloning of $\boldsymbol{R}$ Genes}

\section{Approach}

At the beginning of this project, only four late blight $R$ genes had been cloned: $R 1, R 3 a$, $R p i-b l b 1$ and Rpi-blb2. The nomenclature of late blight is as follows: $R$ genes from $S$. demissum are named $R 1$ till $R 11$. Late blight $R$ genes from other species are abbreviated as $R p i$ (resistance against $P$. infestans) followed by the abbreviations of the species name (blb from $S$. bulbocastanum, vnt from Solanum venturii, etc.). The subsequent number refers to the order of cloning of a particular $R$ gene from that wild species. Broad-spectrum $R$ genes recognise many isolates of $P$. infestans, and narrow-spectrum $R$ genes with only few. Therefore, under field conditions, potato genotypes containing narrow-spectrum $R$ genes become infected more rapidly than genotypes with broad-spectrum $R$ genes.

At the beginning of this project, only four late blight $R$ genes had been cloned: $R 1$, $R 3 a, R p i-b l b 1$ and Rpi-blb2. The number and isolate resistance spectra of these $R$ genes 
were limited, and it was necessary to clone additional $R$ genes. In the DuRPh sub-project 'cloning', which ran from 2006 through 2010, we set out to genetically map and clone additional broad-spectrum $R$ genes from various crossable Solanum species. Also in parallel projects, $R$ genes were being cloned. Now, more than $20 R$ genes are available for transformation (Rodewald and Trognitz 2013). In the next sections, the progress obtained through the DuRPh project is described in the order of the successive steps of the map-based cloning strategy.

\section{Mapping}

A requirement for $R$ gene cloning is the ability to genetically map the target gene. At the beginning of the project, several small research populations $(n=50-100)$ were analysed for segregation of resistance using detached leaf assays. The studied resistance sources were the diploid species Solanum berthaultii, Solanum tarijense and Solanum chacoense from Bolivia; the diploid Argentinian species Solanum rechei; the diploid Mexican species Solanum pinnatisectum; and potato genotypes with introgressed $R$ genes from the Mexican hexaploid species $S$. demissum (SH 83-92-488, harbouring the genes $R 3 b$; Black's differential 3053(18), also known as Ma[stenbroek's]R5; Black's differential 2424a(5) also known as MaR8; Black's differential 2573(2), also known as $\mathrm{MaR} 9$; potato variety Sarpo Mira). Important new insights were obtained during these genetic studies, such as the observation that some resistances were poorly or not at all expressed in detached leaf assays (MaR5, MaR8, MaR9, Sarpo Mira, S. rechei) but were clearly expressed in field trials. Also, a remarkably high number of populations were found in which more than one $R$ gene was segregating. This is an important insight to understand durability, but it also hampered the mapping and cloning of the underlying $R$ genes. In the populations that were derived from the $\mathrm{Ma} R 5, \mathrm{Ma} R 8$ and $\mathrm{Ma} R 9$ plants, a combination of diagnostic $R$ gene markers was used and recognition of cognate $A v r$ genes was performed. In this way, the presence of the $S$. demissum genes $R 1, R 2$ and $R 4$ in MaR5; $R 3 a, R 3 b$ and $R 4$ in MaR8; and $R 1, R p i-a b p t$ (a functional homolog of $R 2$ ), $R 3 a, R 3 b$ and $R 4$ in MaR9 was demonstrated (Kim et al. 2012). To successively map additional resistance genes from $\mathrm{Ma} R$, additional backcrosses were made to susceptible plants, an approach referred to as de-stacking. Ultimately, populations were selected in which the $R 9 a$ gene segregated in a 1:1 ratio (Jo et al. 2015). Other $R$ genes, like $R 8$ (Jo et al. 2011), were mapped using differential isolates that are recognised by only $1 R$ gene in the population. With respect to the use of differential isolates, synergy was achieved with the DuRPh sub-project 'resistance management' in which $P$. infestans isolates were collected and classified in $R$ gene virulence races. A multitude of tested plant populations were not useful because the resistance segregated in a quantitative fashion, or segregation was highly skewed towards resistance due to stacking of multiple $R$ genes. A total of 11 plant populations were developed that segregated for resistance and susceptibility in a 1:1 ratio.

\section{Fine-mapping}

In order to fine-map the genes that were segregating in a 1:1 ratio, mainly two different approaches were used. A biased-based on beforehand knowledge-approach was undertaken in the case of the $S$. chacoense, S. berthaultii and S. pinnatisectum 
populations since map positions had been described on chromosome 10 (S. berthaultii which is highly related to $S$. chacoense accessions from Bolivia) and chromosome 7 ( $S$. pinnatisectum). Fine-mapping for the chromosome 10 and chromosome 7 genes was performed using reference genome sequences. At the start of the DuRPh project, the potato genome sequence was not available yet and a 500-kb region from chromosome 10 of potato clone RH89-039-16 was sequenced within this project. Later, the genome sequence of a doubled-monoploid (DM) $S$. phureja clone was used as a reference (The Potato Genome Sequencing Consortium 2011).

Initial attempts to clone the $R 8$ gene using a biased approach failed because the gene was not present on chromosome 11, contrary to what was reported in the literature. An unbiased genome-wide, nucleotide binding site (NBS) profiling screen (Vossen et al. 2013) revealed $R$ gene clusters in the vicinity of the $R 8$ gene (Jo et al. 2011) on chromosome 9 . Successive $R$ gene cluster directed profiling successfully identified closely linked markers in chromosome 9 in this tetraploid material. Also, the $R 9 a$ gene was fine-mapped using a similar approach (Jo et al. 2015).

\section{$\boldsymbol{R}$ Gene Cloning}

All late blight $R$ genes cloned so far are located in complex clusters of highly homologous genes, which requires specialised cloning strategies. Roughly, two cloning approaches can be distinguished, positional cloning and homologybased cloning, each associated with different virtues and drawbacks, and sometimes a combination of both strategies was used. Positional cloning requires fine-mapping in a large population, successive marker landing in a bacterial artificial chromosome (BAC) library and sub-cloning of the candidate genes. In the homology-based cloning approach, the laborious fine-mapping and BAC landing process is bypassed and candidate genes are directly cloned by suspected homology to known $R$ genes. The positional cloning approach has been successfully applied for the Rpi-chcl (Vossen et al. 2011) and $R 3 b$ genes (Li et al. 2011). Positional cloning of the Rpi-pnt1 and $R 8$ genes was in an advanced stage at the end of the sub-project. The positional cloning of $R 8$ was successfully finished afterwards (manuscript under review; Fig. 1). A combined map-based and homology-based cloning approach was successfully pursued for Rpi-ber from $S$. berthaultii and Rpi-tarl from $S$. tarijense, which are allelic variants of Rpi-chcl. The homology-based cloning approach is faster and more productive than the positional cloning approach. However, purely homologybased cloning strategies were not always successful in identifying new resistance specificities, as often known $R$ genes are re-isolated, like $R 2$ and $R 3 a$ (Wang et al. 2008; Kim et al. 2012). Homology-based cloning strategies were, however, also successfully pursued for the isolation of $R$ genes with novel recognition specificities. Additional genes from $S$. chacoense (Rpi-chc2) and $S$. berthaultii were identified because of their homology to Rpi-chc1, but those recognised a non-overlapping set of effectors from the same $P$. infestans isolate. It still remains to be determined how the resistance spectra of the new Rpi-chcl homologs overlap after transformation to the variety Désirée.

Furthermore, much insight was gained on the $R$ gene stacks and their potential contribution to durability of resistance in the variety Sarpo Mira (Rietman et al. 2012), 


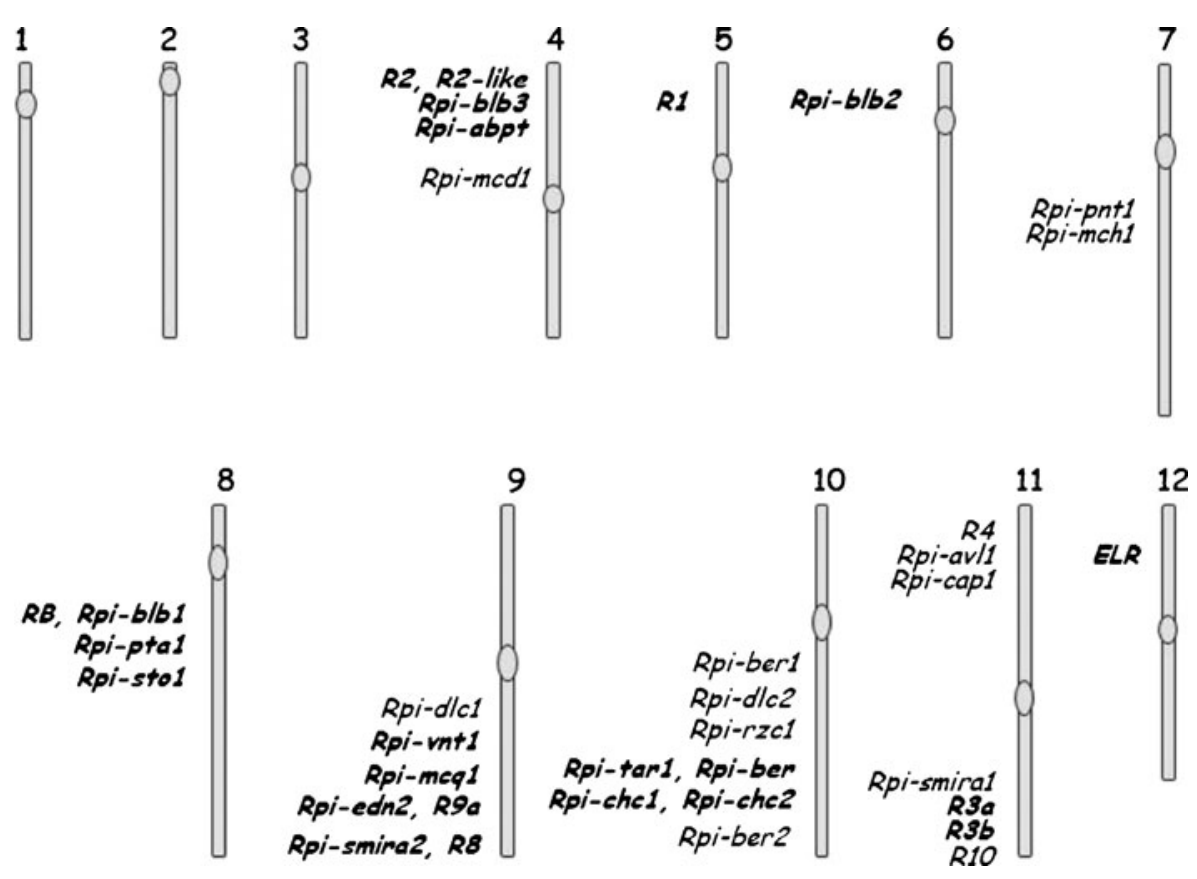

Fig. $1 R$ genes mapped (regular font) and cloned (bold font) as described in the literature completed with unpublished DuRPh results. Vertical bars represent the 12 chromosomes of potato

$\mathrm{MaR} 8$ and $\mathrm{MaR} 9$ (Jo et al. 2016). In a parallel project, also the $R 9 a$ gene was cloned using a combined homology-based and positional cloning approach (Jo 2013). Figure 1 shows the $R$ genes mapped and cloned, as described in the literature and based on (un)published results from DuRPh and adjacent projects.

\section{Sub-project 2: Transformation of Potato Varieties with $\boldsymbol{R}$ Genes}

\section{Approach}

Single late blight $R$ genes or combinations of two to three $R$ genes were cloned into binary vectors which were derived from pBINPLUS, a binary vector for A. tumefaciens-mediated plant transformation. Three varieties were selected for transformation: Première (early maturing), Désirée (middle late maturing) and Aveka (late maturing with a high level of field resistance). At later stages of the project, depending on the scientific hypotheses, also other varieties were used. Initially, to rapidly establish a genetic material and to test the effect of $R$ gene stacking on the epidemiology of the disease in the field, marker-assisted transformations were made using the nptII (coding for resistance to the antibiotic kanamycin) as a selectable marker gene. Once $R$ gene/variety combinations and/or $R$ gene combinations were validated using marker-assisted transformation, these combinations were eligible for marker-free transformation to produce cisgenic varieties. 


\section{Selection of Non-redundant Broad-Spectrum Genes for Transformation}

As shown in the previous section (Fig. 1), at present, more than $20 R$ genes are cloned and available for transformation. Most of these cloned $R$ genes have been transformed individually into Désirée. This resulted in an isogenic differential set, because all $R$ genes are in the same genetic background, i.e. the variety Désirée (Zhu et al. 2015). Each plant differs only by the presence of one $R$ gene. This set is highly instrumental for virulence monitoring, as carried out in sub-project 4 resistance management.

For detailed studies on background dependency and combinability of $R$ genes, we could not use all the cloned $R$ genes. From groups of allelic variants with the same or similar function, only one representative was chosen (Table 1). However, genetic location alone was not sufficient to also define functional redundancy. Syntenic $R$ gene clusters harboured highly similar $R$ genes but with different recognition specificity, like the Rpi-mcq1, Rpi-edn2 and Rpi-vnt1.1 genes. The recognition specificity was defined using the effector or effector family that is recognised. After elimination of functional

Table 1 Classification of cloned $R$ genes based on their genomic location, recognition specificity and resistance spectrum

\begin{tabular}{lllll}
\hline$R$ gene & Chromosome & Cluster $^{\mathrm{a}}$ & Avr & Spectrum $^{\mathrm{b}}$ \\
\hline Rpi-blb3 & 4 & $\mathrm{C} 12$ & Avr2 & Intermediate \\
$R 2$ & 4 & $\mathrm{C} 12$ & Avr2 & Intermediate \\
Rpi-abpt & 4 & $\mathrm{C} 12$ & Avr2 & Intermediate \\
Rpi-edn1 & 4 & $\mathrm{C} 12$ & Avr2 & Intermediate \\
$R 1$ & 5 & $\mathrm{C} 24$ & Avr1 & Narrow \\
Rpi-blb2 & 6 & $\mathrm{C} 28$ & Avrblb2 & Broad \\
Rpi-blb1 & 8 & $\mathrm{C} 40-\mathrm{C} 41$ & Avrsto1 & Broad \\
Rpi-pta1 & 8 & $\mathrm{C} 40-\mathrm{C} 41$ & Avrsto1 & Broad \\
Rpi-sto1 & 8 & $\mathrm{C} 40-\mathrm{C} 41$ & Avrsto1 & Broad \\
Rpi-vnt1.1 & 9 & $\mathrm{C} 42$ & Avrvnt1 & Broad \\
Rpi-edn2 & 9 & $\mathrm{C} 42$ & Avrblb2 & Broad \\
R9a & 9 & $\mathrm{C} 42$ & Avrblb2 & Broad \\
Rpi-mcq1 & 9 & $\mathrm{C} 42$ & Avr2 & Intermediate \\
R8 & 9 & $\mathrm{C} 43$ & Avr8 & Broad \\
Rpi-smira 2 & 9 & $\mathrm{C} 43$ & Avr8 & Broad \\
Rpi-chc1 & 10 & $\mathrm{C} 46$ & Avrchc1 & Broad \\
Rpi-tar1 & 10 & $\mathrm{C} 46$ & Avrchc1 & Broad \\
Rpi-ber & 10 & $\mathrm{C} 46$ & Avrchc1 & Broad \\
Rpi-chc2 & 10 & $\mathrm{C} 46$ & Avrchc2 & Narrow \\
R3a & 11 & $\mathrm{C} 53-\mathrm{C} 54$ & Avr3a & Narrow \\
R3b & 11 & $\mathrm{C} 55$ & Avr3b & Narrow \\
\hline a & & & & \\
\hline
\end{tabular}

\footnotetext{
${ }^{\text {a }}$ Strongest homology to clusters as described by Jupe et al. (2013)
}

${ }^{\mathrm{b}}$ Broad-spectrum resistance $=$ plants harbouring this $R$ gene are resistant to over $80 \%$ of the $P$. infestans isolates from the Netherlands. Narrow-spectrum resistance $=$ plants harbouring this $R$ gene are resistant to less than $10 \%$ of the $P$. infestans isolates from the Netherlands 
redundancy, still $10 R$ genes were available. A third selection criterion was applied that took $P$. infestans isolate resistance spectra into account. $R$ genes with narrow isolate resistance spectra that recognised less than $10 \%$ of the $P$. infestans isolates from a particular area, in our case the Netherlands, were disregarded. Ultimately, a set of five $R$ genes were selected for further studies (Rpi-edn2, Rpi-blb3, Rpi-vnt1.1, Rpi-chc1 and Rpi-sto1).

\section{Marker-Assisted Transformations of Single $\boldsymbol{R}$ Genes}

It was foreseen that for each variety-gene combination, about 50 transgenic events were to be generated. The transformed plants were maintained in vitro and propagated for greenhouse tests to evaluate the functionality of the introduced $R$ genes. The relationship between $P$. infestans resistance in the field, mRNA expression and response to the corresponding Avr gene was established. A clear correlation was found between resistance level and Avr recognition. It was concluded that Avr responsiveness is indicative of the functional expression of the individual $R$ genes. This provided a valuable tool for the analysis of plants with multi- $R$ gene stacks (see the "MarkerAssisted Transformation of Multiple $R$ Genes" section). This also provided a reliable assay to predict, shortly after transformation, whether all $R$ genes in a GM plant will be functionally expressed under field conditions.

To test the performance of the five selected $R$ genes in different genetic backgrounds, transformations of five different varieties were performed. A huge variation was found in the frequency by which late blight resistance events could be selected. This frequency varied between 5 and 95\% depending on the $R$ gene and $R$ gene/variety combination (Table 2). Three $R$ genes performed well in all tested genetic backgrounds, but Rpi-chcl and Rpi-edn2 provided only partial resistance in the majority (95\%) of the Première events.

\section{Marker-Assisted Transformation of Multiple $\boldsymbol{R}$ Genes}

With the selected five broad-spectrum $R$ genes, 10 unique combinations of two $R$ genes could be made. One of these combinations was not stable in $A$. tumefaciens. The other nine combinations of two $R$ genes in one vector could be successfully made and transformed to Désirée. Certain combinations of $R$ genes were less efficiently transformed. Low transformation efficiency was associated with slow growth of the $A$.

Table 2 Transformation of five selected $R$ genes to five different potato varieties

\begin{tabular}{llclll}
\hline$R$ gene & Désirée & Première & Aveka & Atlantic & Bintje \\
\hline Rpi-edn2 & 95 & 5 & 90 & 95 & - \\
Rpi-blb3 & 90 & 80 & 80 & 90 & 80 \\
Rpi-vnt1.1 & 95 & 95 & 90 & 95 & 80 \\
Rpi-chc1 & 50 & 5 & 45 & 50 & - \\
Rpi-sto1 & 75 & 80 & 80 & 85 & 90 \\
\hline
\end{tabular}

Percentages of resistant events (40-70 events per variety-construct combination were tested) are indicated 
tumefaciens clone and resulted in longer regeneration times of transgenic events. The selected transgenic events were screened for functional expression of both introduced $R$ genes using differential isolates and Avr responsiveness. The frequency by which both introduced $R$ genes were functionally expressed varied considerably between constructs ranging from 0 to $95 \%$. By systematically testing all combinations, a clear picture was formed of optimal, sub-optimal and impossible combinations. For eight $R$ gene combinations, we selected events in which both $R$ genes are active. This digenic differential set could be used alongside the monogenic differential set for durability studies as described in sub-project 4 resistance management.

With the selected set of five broad-spectrum $R$ genes, 10 unique combinations of three $R$ genes can potentially be made. Three of these combinations in one vector were made, but one of the constructs could not stably replicate in $A$. tumefaciens. A. tumefaciens transformants that stably replicated the two remaining constructs (Rpi-vnt1.1:blb3:sto1 and Rpi-sto1:vnt1.1:chc1) showed extremely slow growth on petri dishes. Both constructs were transformed to Désirée, and a very long regeneration time was observed. Among the transgenic events, obtained using Rpi-sto1:vnt1.1:chc1, only a minority contained the complete transfer DNA (T-DNA). None of the plants with the complete T-DNA functionally expressed all three $R$ genes. Transformation of Rpi-vnt1.1:blb3:sto1, on the other hand, was very successful. The majority of the transgenic events harboured the complete T-DNA and also functionally expressed all three $R$ genes (Zhu et al. 2013). It remains to be tested how efficiently the remaining seven combinations of three $R$ genes can be made and transformed. The knowledge obtained by making all possible combinations of two $R$ genes is instrumental to design optimal constructs of three $R$ genes.

During the course of these transformation experiments, many different constructs with different T-DNA lengths were tested for the average regeneration time of events (Fig. 2). Among the constructs in the same transformation vector, there was a tendency for larger T-DNA inserts to correspond with a longer regeneration time.

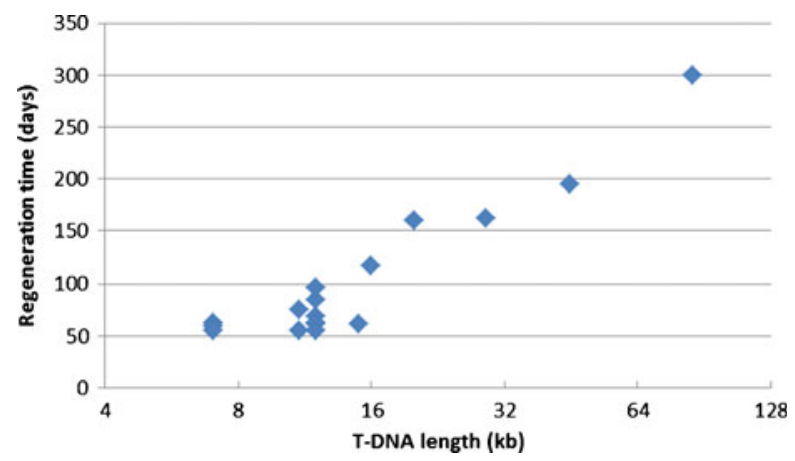

Fig. 2 The relationship between T-DNA length and shoot regeneration time. The average regeneration time of kanamycin-resistant shoots after transformation is presented. A maximum of 50 shoots per transformation were harvested. The three data points on the right $(30,48$ and $95 \mathrm{~kb})$ represent biBAC constructs that contain fragments of Solanum sp. genomic DNA. The other data points represent late blight $R$ genes and combinations thereof in pBINPLUS 


\section{Marker-Free Transformations}

In order to make plants that contain cisgenes only, we did not use the selectable marker genes. Because potato transformation is quite efficient, a marker-free transformation approach was pursued to make cisgenic late blight resistant potato plants (de Vetten et al. 2003). Initially, only single $R$ genes were transformed to validate the marker-free transformation protocol for $R$ gene constructs. $R 3 a$ and $R p i$-vnt 1.1 could be efficiently transformed into Désirée and Atlantic (Table 3). Roughly half of the marker-free transformation events were free of vector backbone sequences and can be referred to as cisgenic events.

Next, we set out to transform combinations of two or three $R$ genes. Differences in marker-free transformation efficiency between varieties, which were clear in markerassisted selection, were hardly observed (Jo et al. 2014; Table 3). Unfortunately, two constructs could not be transferred at all and others were transferred with very low efficiencies only. It must be noted that many of these experiments were done prior to the systematic study of $R$ gene combinability. In retrospect, the $R$ gene combinations in the marker-free transformation constructs could have been considered better. Some constructs, however, could be transferred efficiently such as Rpi-sto1:vnt1.1. Many rejected events were found in some successful transformations such as with Rpisto 1:blb3 and Rpi-vnt1.1:chc1 due to high levels of vector backbone, broken T-DNA and a low frequency of functional expression of the introduced genes. As no optimal combinations of three $R$ genes were found until 2013, when sub-project 2 ended, no marker-free transformation events with three $R$ genes in one T-DNA were produced.

To assure the achievement of one of the projects objectives, a cisgenic variety with three $R$ genes, the approach of re-transformation was chosen. From the variety Atlantic, a well-characterised true-to-type cisgenic event harbouring a single T-DNA integration of Rpi-sto1:vnt1.1 (H43-4k; Table 4) was re-transformed with the Rpi-chc1 gene. Out of 20 marker-free transformation events, four cisgenic events (M49; Table 4) were selected that functionally expressed all three $R$ genes. These four events were made available for the 'selection' and resistance management sub-projects 3 and 4 of DuRPh, respectively.

Table 3 Marker-free transformation efficiencies

\begin{tabular}{llll}
\hline & Désirée & Atlantic & Bintje \\
\hline R3a & 1 & & \\
Rpi-vnt1.1 & 4 & 4 & \\
Rpi-chc1 & 2 & 3 & 2 \\
Rpi-sto1:blb3 & 0.3 & 0.5 & \\
Rpi-vnt1.1:sto1 & & 1 & \\
Rpi-chc1:vnt1.1 & 0.1 & 0.1 & \\
Rpi-chc1:vnt1.1:blb3 & 0 & & \\
Rpi-sto1:blb3:vnt1.1 & 0 & & \\
\hline
\end{tabular}

More than 2000 shoots per variety-construct combination were tested, and percentages of PCR-positive shoots are shown 
Table 4 Number of GM events in 2014 in the yield and/or late blight resistance field trial per variety and construct. Only the marker-free constructs are cisgenic events

\begin{tabular}{|c|c|c|c|c|c|c|}
\hline \multirow{2}{*}{$\begin{array}{l}\text { Transformation } \\
\text { code }\end{array}$} & \multirow[t]{2}{*}{ T-DNA insert } & \multicolumn{5}{|c|}{ Genotype } \\
\hline & & $\begin{array}{l}\text { Désirée } \\
\text { (A) }\end{array}$ & $\begin{array}{l}\text { Première } \\
\text { (B) }\end{array}$ & $\begin{array}{l}\text { Aveka } \\
\text { (C) }\end{array}$ & $\begin{array}{l}\text { Atlantic } \\
(\mathrm{H})\end{array}$ & $\begin{array}{l}\mathrm{H} 43-4 \mathrm{k} \\
(\mathrm{M})\end{array}$ \\
\hline 01 & Rpi-blb1 & 3 & 3 & 3 & & \\
\hline 03 & Rpi-blb3 & 1 & & & 4 & \\
\hline 04 & $R 3 a$ & 1 & & & & \\
\hline 08 & $R 3 a$ marker free & 2 & & & & \\
\hline 09 & Rpi-stol & 4 & & & 4 & \\
\hline 10 & Rpi-sto1:blb3 & 3 & & & & \\
\hline 13 & Rpi-vnt1.1 & 3 & 3 & 3 & 4 & \\
\hline 14 & Rpi-sto1:blb3:vnt1.1 & 4 & & & & \\
\hline 15 & Rpi-vnt1.1 marker free & 3 & & & 5 & \\
\hline 16 & Rpi-sto1:vnt1.1 & 3 & & & & \\
\hline 17 & Rpi-chcl & 3 & & 2 & & \\
\hline 19 & Rpi-vnt1.1:chc1 & 3 & & & & \\
\hline 23 & Rpi-ptal & 3 & & & & \\
\hline 25 & $R 3 b$ & 3 & & & & \\
\hline 26 & $\begin{array}{l}\text { Rpi-blb3:sto1 marker } \\
\text { free }\end{array}$ & 3 & & & & \\
\hline 31 & Rpi-mcq1 & 3 & & & & \\
\hline 43 & $\begin{array}{l}\text { Rpi-sto 1:vnt1.1 marker } \\
\text { free }\end{array}$ & & & & 2 & \\
\hline 49 & Rpi-chcl marker free & & & & 2 & 4 \\
\hline 55 & Rpi-vnt1.1:blb3 & 5 & & & & \\
\hline 56 & Rpi-vnt1.1:edn2 & 12 & & & & \\
\hline 73.1 & Rpi-edn2 & 9 & & & & \\
\hline
\end{tabular}

\section{Sub-project 3: Selection of Cisgenic True-to-Type Events}

\section{Approach}

The objectives of the DuRPh sub-project selection were to select suitable transformation events for further studies in sub-project 4 resistance management. Molecular analyses were carried out to determine the number of T-DNA insertions. For this purpose, we initially used Southern blots which were probed with the nptII gene. TDNA copies in marker-free transformation events could not be determined using Southern blots because the probe DNA was derived from the inserted late blight $R$ genes and recognised high numbers of endogenous sequences in the genome of the transformed potato variety. We therefore adopted a quantitative PCR with late blight $R$ gene-specific primers to estimate the number of T-DNA copies. Events with T-DNA copy numbers above five were discarded. Also, a vector backbone screening was carried out to eliminate the events that carried these undesirable sequences. Next, the 
events were evaluated for late blight resistance in detached leaf assays and in the field. A selection of events was made that showed no variation in above-ground morphology, maturity type, tuber yield and tuber characteristics in comparison to the original variety, a true-to-type analysis. The genotypes that - according to the Union for the Protection of New Varieties of Plants (UPOV) characteristics - are undistinguishable from the original variety are suitable for the creation of a dynamic variety. A dynamic variety consists of a number of isogenic clones that only vary with respect to the inserted $R$ genes. Which isogenic clones will be grown in the future will vary in time and space according to the prevailing pathotypes of $P$. infestans. The level of expressed resistance was determined both in the tubers and in the foliage of the GM plants and compared to the original non-transformed variety. The description and analysis of the complete selection process was to identify bottlenecks and structural problems to improve future breeding efforts with GM potato.

Two in vitro plantlets per event were transferred to the greenhouse where their resistance level was assessed by means of detached leaf assays. A molecular analysis assessed the number of insertions, and a first visual evaluation was applied to select genotypes that morphologically showed similarity to the original variety. Events containing constructs with multiple $R$ genes were screened in the greenhouse to verify the efficacy of each individual $R$ gene. Therefore, GM plants were subjected to tests with different $A v r$ genes of $P$. infestans.

For sub-project 4 resistance management, some events were selected. These events were multiplied in vitro whereby 12 or 24 in vitro plantlets were transferred to 5-1 pots with arable sandy soil in a screenhouse for renewed morphological characterisation and production of healthy seed tubers for subsequent seed multiplication in the field, and for use in various field experiments. Seed tuber production of GM plants was compared to seed tuber production, also of in vitro plantlets, of the original variety. Field trials consisted of resistance level assessments after artificial inoculation with the $P$. infestans isolate IPO-C $(1,2,3,4,5,6,7,10,11)$, an isolate often used as a standard at Wageningen UR that is known to have broken most of the $11 \mathrm{~S}$. demissum $R$ genes. Simultaneously, two field trials were planted: the inoculated one to assess expression of resistance and the other one where the same genotypes were planted but late blight was controlled chemically. In these protected trials, annually, true-to-type assessment took place on foliage, flowering behaviour, maturity type and tuber appearance. Over the years, tubers of GM plants were subjected to the following: (1) visual observations of shape, size, tuber number, size distribution, skin colour, flesh colour, internal and external defects and sprouting; (2) weight; (3) indirect estimation of specific gravity by underwater weighing; and (4) quality checks on boiled and fried product. Selection in the greenhouse and screenhouse started in the second year of the DuRPh project; the field trials and multiplication stages started in 2008, the third year; and evaluation of newly produced and/or already selected events continued until the end of the project in 2015.

In 2008, 2009 and 2010, the field experiments were carried out in accordance to licence IM 07-001 issued by the Netherlands Ministry of Environment. This licence allowed planting of GM plants with 10 well-described constructs 
in field plots at maximally five well-described trial sites. The 2011 and 2012 field trials were planted according to licence IM 09-002, allowing a wider range of plasmids and constructs used for transformation. Later, a new licence (IM-L 12-002) was granted, allowing planting of GM plants obtained through re-transformation, co-transformation and crosses.

\section{Selections}

The number of GM plants throughout the years varied considerably due to the increased availability of $R$ genes, $R$ gene stacks, marker-free cisgenic events and varieties transformed; reduced availability followed when GM plants were rejected with insufficient expression of the inserted $R$ gene or genes, bacterial backbone and/or any kind of disturbing deviations from the original variety. This resulted in the events evaluated in the 2014 field trial as shown in Table 4 with field views as for instance shown in Fig. 3.

Initially, the primary goal of the sub-project selection was to select the best GM plant-taking into account all evaluated characteristics-of each 'variety $\times$ construct' combination. Later, the focus turned to selecting three GM plants per combination, allowing us to have botanical replications in all kinds of research experiments. Besides supplying GM plants to the DuRPh subproject resistance management, the selected GM plants were used in nonDuRPh research projects such as by the University of Leiden in a so-called Ergo project that was seeking metabolites and effects on nematodes and by a Belgian consortium in Ghent that carried out late blight resistance research after natural infection occurring during the 2010 and 2011 growing seasons (Haesaert et al. 2015). The Netherlands State Institute RIKILT that covers food safety issues used samples to test glycoalkaloid concentrations in GM plants. Two EU projects too, GMO Risk Assessment and Communication of Evidence and AMIGA (GRACE) - assessing and monitoring the impacts of genetically

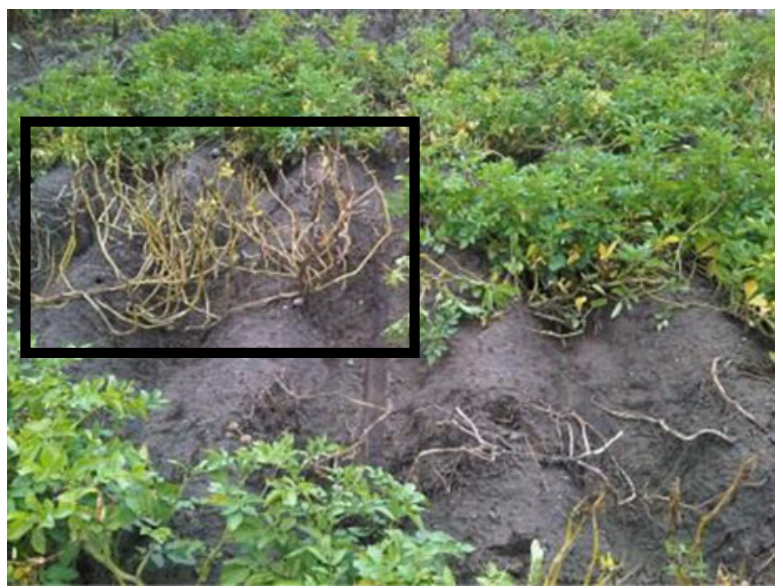

Fig. 3 Late blight trial field showing the original variety Première (black rectangle) surrounded by GM Première plants containing one or more $R$ genes 
modified plants on agro-systems - and both EU Seventh Framework projects used GM plants produced by the DuRPh project.

In 2013, a tuber resistance test for $P$. infestans was developed and GM events were subjected to this test as shown in Fig. 4. Expression of tuber resistance depended on the $R$ gene and on background. It was found that some $R$ genes that lead to resistance in the leaves in the variety Désirée such as Rpivnt1.1 also convey a high level of resistance in the Désirée tubers. Background dependency, however, was found for Rpi-stol which did not significantly lower the tuber susceptibility in the variety Désirée, whereas it did in the variety Aveka.

The Désirée transformants (A55-, A56, A73.1) were planted as in vitro plantlets in the field and the rest, in 2014, as tuber seeds. H43-4k is a cisgenic Atlantic plant (Rpi-sto 1:vnt1.1 marker free) which was used for retransformation with $R p i$-chcl. Regarding true-to-type variation, clear differences may appear between foliage and tuber characteristics. While varieties Désirée and Première produced considerable numbers of variants with deviating foliage and/or tubers, GM plants of the variety Aveka hardly showed divergences in foliage appearance but many GM plants showed tubers with a deviating shape caused by secondary growth or an altered length-to-width ratio tending towards longer tubers. Deviation frequency from true-to-type increased, when larger constructs were transformed, and was associated with a longer regeneration time. Besides observing a true-to-type variation in the greenhouse and field in foliage and tubers, tubers of a series of 40 Désirée and Première GM plants were subjected to diffuse light to undergo evaluation according the UPOV light sprout characteristics. All but one event (Fig. 5) were found to be identical to the original variety according to the UPOV light sprout characteristics. This only deviating event was found to be not true-to-type in a successive field trial as well.

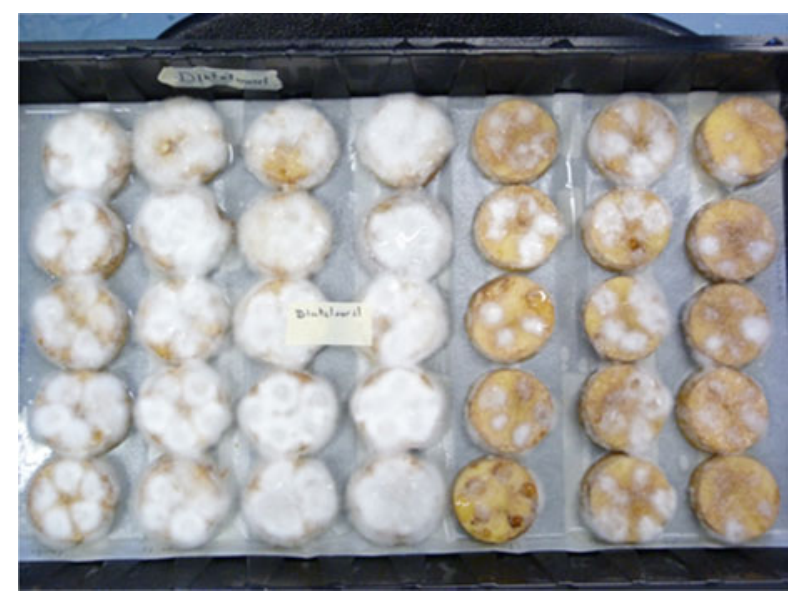

Fig. 4 Infected tuber discs of the variety Désirée (middle vertical row), three GM Désirée plants with a nontuber functional $R$ gene (three rows on the left) and three GM Désirée plants with a tuber-expressed $R$ gene (three rows on the right) 


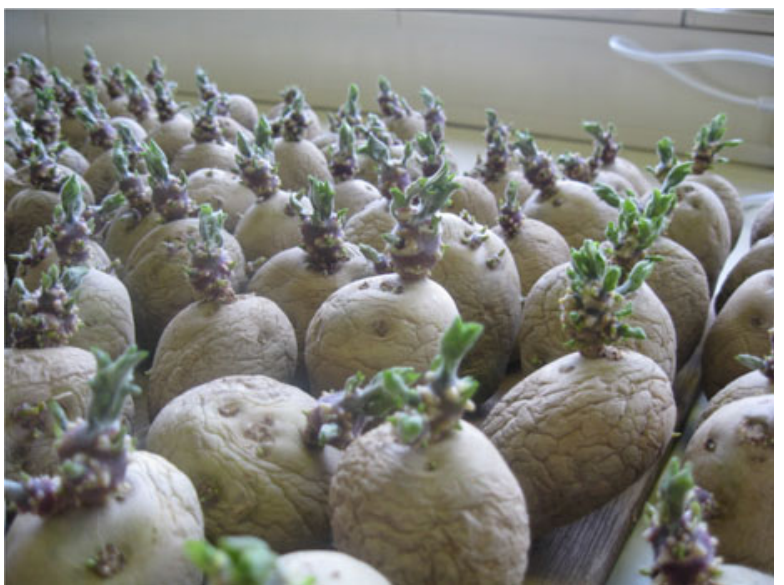

Fig. 5 True-to-typing through diffused light sprout analysis. All rows show variety Désirée transformants that are true-to-type, except the row on the right which is a transformant of Désirée showing somaclonal variation (leafier sprouts)

\section{Sub-project 4: Resistance Management}

\section{Background and Approach}

Host resistance to potato late blight is an adequate tool to enhance the durability of potato cultivation. In the past, it was, however, repeatedly shown that $R$ gene-mediated host resistance was easily overcome by $P$. infestans (e.g. Black et al. 1953), especially if the resistance is based on a single $R$ gene. The origin of the strong adaptive capability of $P$. infestans resides in its genome in combination with its reproductive capacity. Fastevolving effector $R$ genes, necessary for infection, are localised in highly dynamic and expanded regions of the $P$. infestans genome (Haas et al. 2009). In addition, $P$. infestans produces large numbers of progeny and sporulation densities of 100 to 500 sporangia/ $\mathrm{mm}^{2}$ of potato leaf (e.g. Flier and Turkensteen 1999; Flier et al. 2007) in combination with a leaf area index (LAI) of e.g. 4 can lead to a progeny of $4 \times 10^{12}$ to $2 \times 10^{13}$ sporangia/season/ha of potato.

Resistance genes are most likely overcome when they are subjected to strong selection pressure by exposing the resistant crop to a large $P$. infestans population, by planting large areas of the resistant crop or, in the worst case scenario, both. The mechanism behind adaptation is mutation and selection aided by recombination and additional genetic variation generated through the sexual cycle. An $R$ gene that is overcome results in an initially tiny fraction of the $P$. infestans population that is compatible with this $R$ gene. This fraction is dynamic and will increase or decrease depending on circumstances (Skelsey et al. 2005, 2010). When it is zero or very small, the $R$ gene is referred to as broad spectrum, and when this fraction is high, the $R$ gene is referred to as narrow spectrum. From the largely random trial and error nature of the mechanism responsible for $R$ genes being overcome, it can be derived that overcoming a set of different $R$ genes is less likely and takes longer. This is because a much rarer event or a series of specific random events are necessary to overcome several $R$ genes in a single event or several $R$ genes in a sequence of random events. Moreover, $P$. infestans is 
continuously involved in an internal competition from which the most rapidly reproducing genotype(s) will prevail and become dominant resulting in increasingly aggressive $P$. infestans genotypes and clonal lines such as EU13_A2 (Cooke et al. 2012).

The durability of resistance and the subsequent durability of potato cultivation can be enhanced in a number of ways: The design phase should aim at producing $R$ gene stacks with a $P$. infestans effector recognition spectrum as wide as possible. During the subsequent exploitation phase, a $P$. infestans monitoring programme in combination with a preventive potato late blight control strategy, specifically developed for resistant varieties, aims at delaying adaptation as much as possible. The last phase in the life of a resistant variety is the replacement phase when late blight buffering cropping systems can minimise the consequences until a (stacked) resistance is completely overcome. The resistant variety is preferably replaced by a new variety, or the same variety with a new stack of $R$ genes, with still intact resistance. This re-sets the $P$. infestans adaptation process and re-starts the cycle.

\section{The Design Phase}

The design takes into account that the larger the stack of $R$ genes and the wider the $P$. infestans effector recognition spectrum, the more difficult it is to overcome the resistance of the stack. Experience from the past and practical limitations to the transformation process indicate that we can currently and realistically aim for three to four $R$ genes per stack.

\section{The Exploitation Phase}

At the introduction of a resistant variety, the $R$ gene stack should as much as possible convey resistance to all locally present $P$. infestans races. In this first stage, in the exploitation phase of a resistant potato variety, there is no need for additional fungicide protection. A continuous $P$. infestans monitoring programme should, however, be in place to yield direct insight in the $P$. infestans adaptation process at population level. The second stage in the exploitation phase of a resistant variety commences when the $R$ gene stack is at risk of being overcome, e.g. when virulence to all but one $R$ gene is found overcome. When this is the case, it is needed to switch from non-spraying to a low-input spray strategy. The release of single $R$ gene varieties should be avoided, but if done so, they should always receive additional low input protection from a fungicide to protect the $R$ gene. The switch from non-spraying to spraying is thus made based on monitoring information and always takes place before the $R$ gene stack is overcome. This allows farmers to benefit longer from the high level of host resistance. Fungicides and $R$ genes both significantly reduce the $P$. infestans infection efficiency, i.e. the number of lesions produced per spore as defined by e.g. Lalancette et al. (1988). Therefore, at least hypothetically, they complement each other. Here, we aim to protect $R$ genes using a low-input spray strategy. Vice versa, $R$ genes may serve to protect vulnerable active ingredients of fungicides. This can already be done through a preventive control strategy and very low dose rates of protectant fungicides as illustrated by e.g. Fry (1977) and Nærstad et al. (2007). This strategy reduces the use of active ingredients by about $75 \%$ from the start of phase 2 of the exploitation phase. During stage 1, the variety does not need to be protected at all. The spray strategy is preventive, and the timing of application 
is critical, as is currently also the case, and is preferably determined by a decision support system (DSS). A DSS identifies past and future infection events and only schedules sprays just prior to predicted infection events. Then, farmers thus only spray when really necessary and the protection level is highest when the infection risk is highest. The choice of fungicide is guided by the DSS (e.g. the EuroBlight Fungicide Table, www.Euroblight. Net). The DSS distinguishes applications prior to infection (protectants), applications shortly after infection (curative fungicides) and applications on visible infections (eradicant applications).

\section{The Replacement Phase}

Whereas stacking $R$ genes, virulence monitoring and fungicide applications are all intended to delay the adaptation of $P$. infestans and to prevent infection, late blight buffering cropping systems are intended to minimise the consequences once the $R$ gene stack is overcome. By alternating $R$ gene stacks in space, within fields or within regions, the epidemic development of a new, virulent $P$. infestans genotype will be buffered since more of the sporangial progeny falls on non-hosts and resistant hosts. As a result, the fraction of compatible $P$. infestans in the population is reduced. This slows down the late blight epidemic at regional level and allows the growers a little more time to react to an emerging epidemic by new $P$. infestans genotypes. Prior to or at this point, the $R$ gene stack overcome can be replaced by e.g. the same variety with a different $R$ gene stack, resulting in alternation of $R$ genes in time. Application of this concept of dynamic varieties ideally would re-set the adaptation process in the $P$. infestans population to avoid or further delay the use of fungicides on resistant varieties.

\section{Experiments}

\section{Monitoring of Virulence}

From the onset of the project, it was assumed that large, genetically highly variable $P$. infestans populations such as encountered in the Netherlands are capable of overcoming any form of monogenic or polygenic host resistance when given the opportunity. It was therefore necessary to monitor, as of the 2006 baseline, the progress of the local $P$. infestans population towards overcoming new $R$ genes and $R$ gene stacks during the project period. For this purpose, so-called 'monitoring fields' were planted annually in Lelystad and Valthermond in the Netherlands. Monitoring fields contained GM monogenic and stacked $P$. infestans $R$ genes in a Désirée background plus the original susceptible Désirée, other commercial varieties, breeding clones and wild Solanum spp. The plant material in these fields was exposed to the local P. infestans population without additional fungicide protection. The date of first infection was observed per clone, and $P$. infestans pure cultures were collected, stored and characterised genotypically and phenotypically.

In general, clones with higher levels of resistance were infected later during the growing season. This delay of infection was calculated per clone as the difference in days between the first infection in the field and subsequent infection of the clone, applying the statistical censor method (Taylor 1973). This resulted in the creation and exploitation of the modified conventional $R$ 

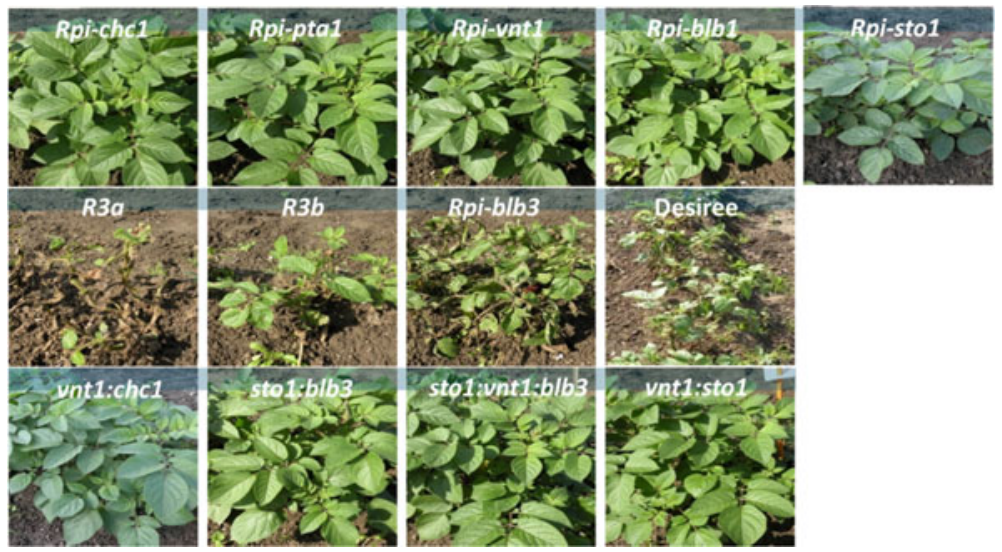

Fig. 6 GM late blight $R$ gene differential set of Désirée with wild-type, single and multiple $R$ gene stacks as described by Zhu et al. 2015. Images were taken on August 19, 2011, at the Lelystad site

gene differential set and the first GM P. infestans differential set (Fig. 6) as described by Zhu et al. (2015).

Figure 7 shows an example of the kind of results obtained in the 2011 monitoring plot in Lelystad. The delay of first infection is given for a number of Désirée clones with a different additional $R$ gene content. The first infection in this field was found on the conventional potato variety Bintje approximately 5 days before the first infection on conventional Désirée. Narrow-spectrum $R$ genes Désirée $R 3 a, R 3 b$ and Rpi-blb3 only gave a short delay of first infection, whereas broader-spectrum $R$ genes Rpi-chcl, Rpivnt1.1, Rpi-sto1 and Rpi-blb1 resulted in a much longer delay of up to 70 days. Stacked $R$ genes did not become infected in Lelystad in 2011, represented by a delay of 90 days resulting from the censor method. In general, virulent isolates for all single $R$ genes included in the monitoring fields were found, earlier or later in the season. Infection of clones containing stacked $R$ genes was rare, and some clones with $R$ gene stacks remained healthy throughout all seasons at both locations.

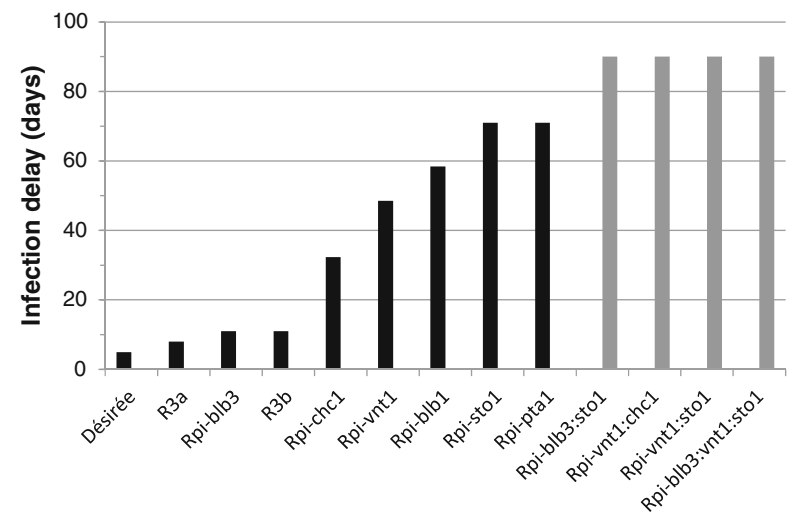

Fig. 7 Virulence monitoring in Lelystad in 2011 using Désirée wild type and GM Désirée with single or multiple late blight $R$ genes. Clone-specific delay of infection (days) is calculated as the difference in days between the first infection in the field and the first infection of the clone using the censor method (Taylor 1973). Delays of 90 days indicate that the clone was not infected at all during this season 


\section{Demonstration of the Complete DuRPh Control Strategy at Field Level}

When the DuRPh project started, it was assumed that the fungicide input could be reduced by at least $80 \%$ through the introduction and management of durable host resistance. To this end, a field demonstration was laid out at the end of the DuRPh project in Wageningen in 2014 and 2015 to demonstrate and test the complete DuRPh control strategy for late blight control on susceptible and resistant potato varieties. The 2014 and 2015 trials also included all lessons learnt in the DuRPh project: from acquisition of pure cisgenic marker-free true-to-type genotypes to stacks of up to three $R$ genes that were obtained through expression of resistance at the field level of broadspectrum and narrow-spectrum $R$ genes and of stacks including broad-spectrum and narrow-spectrum $R$ genes.

Plots measured $7.5 \times 7.5 \mathrm{~m}$. The following clones were represented by two plots: Désirée (wild type), Désirée:Rpi-blb3, Désirée:Rpi-chc1, Désirée:Rpi-blb1, Désirée:Rpi-vnt1.1 and the conventionally bred resistant varieties Bionica, Carolus and Sarpo Mira, this variety in 2015 only. One of both plots received minimal additional fungicide protection, whereas the second plot did not. Additionally, the field contained one plot of the following $R$ gene stack containing clones: Désirée:Rpiblb3:sto1, Désirée:Rpi-vnt1.1:sto1, Désirée:Rpi-chc1:vnt1.1 and Désirée:Rpiblb3:sto1:vnt1.1.

From the monitoring effort, it was known that Désirée:Rpi-blb3 did not result in additional delay of infection when compared to the susceptible wild-type Désirée. Other single $R$ gene clones included were regularly infected in the monitoring fields, although with a large delay of infection. Stacked $R$ gene resistance was found to be more robust and was rarely infected in the monitoring fields (Fig. 7). For this reason, it was decided to consider Désirée and the Désirée:Rpi-blb3 clone as susceptible and spray these clones from the start of the season using a $100 \%$ dose rate of protectant fungicides prior to infection periods. The clones containing a single $R$ gene were sprayed starting after the first infection was observed in the field (2014) or just prior to inoculation (2015) with a $25 \%$ dose rate of protectant fungicides. The conventionally bred varieties Bionica, Carolus and Sarpo Mira were also included in this spray strategy using a $25 \%$ dose rate of protectant fungicides. Désirée clones containing stacks of two or three $R$ genes were not sprayed at all. Spray timing was done using the advice of a decision support system predicting infection events in the near future. Protectant fungicides were applied just prior to a predicted infection event.

Figure 8 shows the number of sprays and the treatment frequency index (TFI, cumulative relative dose rates) needed during the 9 weeks of the 2014 and 2015 growing seasons. The crop was planted mid-June and emerged early July in both years which is later than conventional as to obtain clear differences for demonstration purpose in early September.

\section{The 2014 Season}

Disease pressure was generally very high from the start of the 2014 season. The first preventive spray was applied on July 4 shortly after emergence. As a result of the severe and enduring disease pressure, 10 for Désirée and Désirée $+R p i-b l b 3$ or 9 spray applications for Désirée containing single $R$ genes, Bionica and Carolus were necessary 

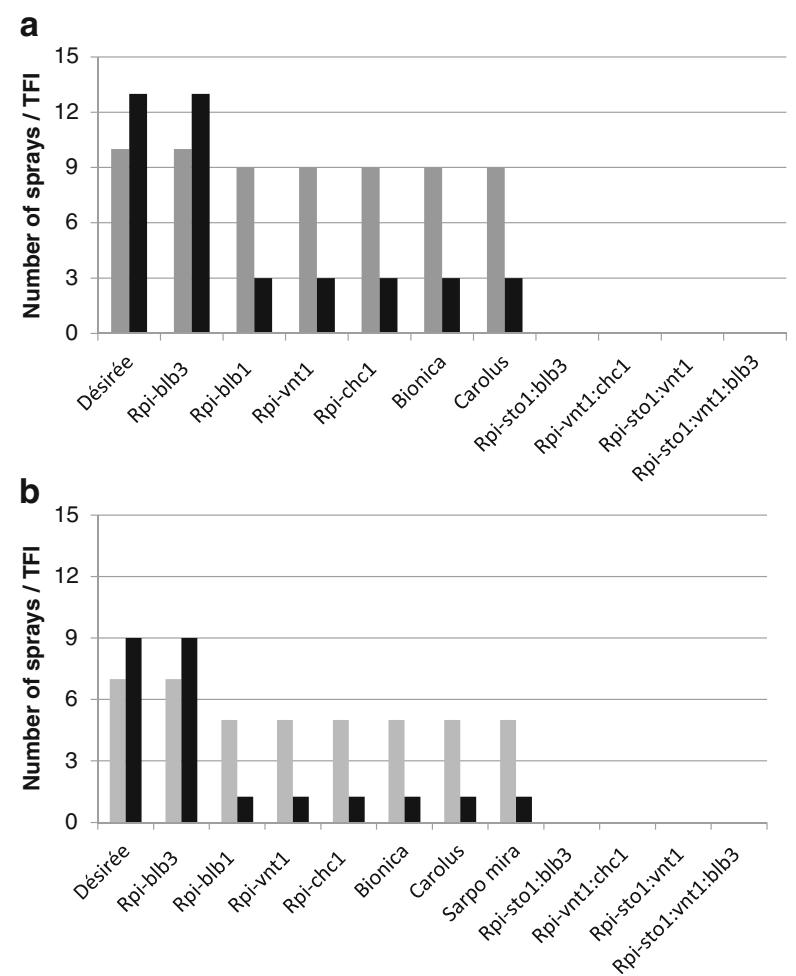

Fig. 8 Number of sprays (grey) and TFI (black, sum of relative dose rates) needed to protect the different clones and commercial varieties in the 2014 (a) and 2015 (b) growing seasons at the Wageningen field demonstration site

during the 9 weeks during which the crop was in the field. The severity level in the sprayed plots at the end of the season was zero for all clones and varieties. The TFI (cumulative relative dose rates) on Désirée and Désirée:Rpi-blb3 was higher than the number of sprays since three, early season, eradicant applications were necessary. Eradicant applications are combinations of curative and anti-sporulant fungicides both applied at their recommended dose rates resulting in a TFI of 2 per application. Désirée clones containing broad-spectrum $R$ genes were sprayed eight times with $25 \%$ of a protectant fungicide plus one time with a curative fungicide at $100 \%$ dose rate. Désirée clones containing stacks of two or three $R$ genes were not sprayed and not infected. Infection levels in the unsprayed plots are given in Fig. 9 upper panel. All susceptible Désirée and single $R$ gene containing clones became infected, which confirms the earlier results from the monitoring fields. Potato clones containing stacked $R$ genes were not sprayed and did not become infected.

\section{The 2015 Season}

Disease pressure during the first half of the 2015 season was very low because of dry weather conditions. Therefore, the 2015 trial was artificially inoculated early August using a sporangial suspension containing 15,000 sporangia/ml of the $P$. infestans isolate NL07041 and a field sprayer at a rate of 300 1/ha. P. infestans NL07041 was originally 

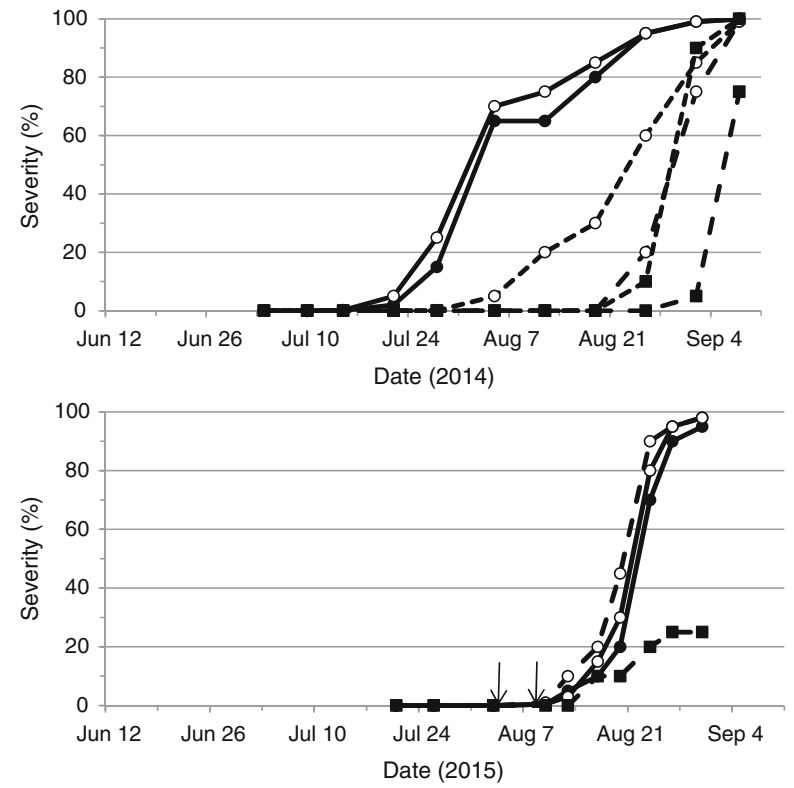

Fig. 9 Severity and percentage of foliage destroyed by P. infestans for 2014 (left to right) (Désirée:Rpi-blb3, Désirée, Désirée:Rpi-blb1, Bionica, Désirée:Rpi-chc1 and Carolus) and 2015 (left to right) (Désirée + Rpiblb1, Désirée:Rpi-blb3, Désirée and Bionica). Arrows indicate artificial inoculations

isolated in 2007 and is part of the EU13-A2, Blue 13, clonal lineage, the most common $P$. infestans genotype in the Netherlands and Europe. Fungicide applications were carried out $24 \mathrm{~h}$ prior to inoculation. The second half of August 2015 was more conducive to late blight development, but the trial was also irrigated overhead for 15 min at dusk and dawn to promote epidemic development. Désirée and Désirée:Rpiblb3 needed seven spray applications at the recommended $100 \%$ dose rate, and Désirée clones containing single $R$ genes, Bionica, Carolus and Sarpo Mira needed five spray applications at a $25 \%$ dose rate during the 9 weeks this crop was in the field. The severity at the end of the season was zero again for all sprayed clones and varieties. The TFI for Désirée and Désirée:Rpi-blb3 was higher than the number of sprays since two eradicant applications were necessary shortly after inoculation. Désirée clones containing stacks of two or three $R$ genes were not sprayed and did not become infected. Infection levels in the unsprayed plots are given in Fig. 9 lower panel. All unsprayed susceptible Désirée, Bionica and some of the single $R$ gene containing clones became infected, confirming earlier results from the monitoring fields. Sarpo Mira and Carolus displayed a few $P$. infestans lesions on lower leaf layers, but infection did not progress. Potato clones containing stacked $R$ genes, as in 2014, were not sprayed and did not become infected.

\section{Sub-project 5: Communication to Society}

The main aim of the DuRPh sub-project 'communication' was to involve stakeholders and the general public by means of communication and interaction. An ultimate goal 
was to give to stakeholders all relevant information about advantages and disadvantages of the development of this cisgenic late blight resistant potato, in such a way that they are able to form a well-balanced opinion about the desirability of growing this potato in the country. A complete acceptation of the end product would not be reached so was not strived for in this DuRPh sub-project.

A second objective of this sub-project was to communicate the advantages and disadvantages of cisgenesis when compared to transgenesis and to develop specific knowledge about national and international societal acceptance of cisgenic marker-free modifications. Discrediting transgenesis in disfavour of cisgenesis was not an aim.

The target groups were potential contributors to the development of a cisgenic resistant potato crop and interested parties that have an opinion about genetic modification. Examples of these groups are policymakers, conventional potato growers, organic growers, breeding and seed potato companies and representatives of the various links of the value chain, namely traders, retailers and consumers. Subsequently, the Netherlands education system was targeted with DuRPh as a case. Learning modules were aimed at pupils themselves, reaching a well-founded opinion regarding genetic innovations. They had to reflect on the use of cisgenesis for sustainable production expressed in socioeconomic, environmental and economic indicators.

\section{Approach}

Where and when possible, the communication sub-project joined other initiatives centring around similar subjects rather than organising meetings by itself. Opinions were elicited from DuRPh rather than only actively offering them, assuming that a message gets across better if asked for. A website (www.durph.nl) was kept up to date with articles and recorded films that were shot in the field. Community was also informed about DuRPh progress and activities in the press, other media, debates and field visits. At national agricultural events, DuRPh researchers were present in stands with information material and lectures. The trial field at Wageningen was opened to the general public yearly, and during the whole project period, several debate sessions were held. In 2014 and 2015, the trials discussed in the previous section were open to the public (Fig. 10). Over the 10-year period, three meetings were organised with

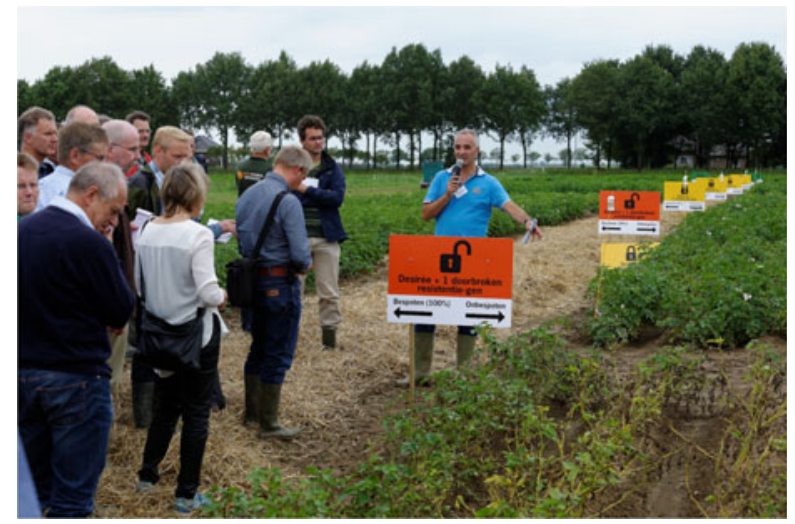

Fig. 10 Public-shown DuRPh field trial with modified late blight resistant plots 
policymakers of the ministries of environment and food safety and economic affairs and agriculture.

\section{Results}

Researchers of the DuRPh research team have been involved in hundreds of presentations on radio and television, presentations at conferences and scientific publications and miscellaneous activities such as webinars and organisation of demonstration days open to the public (Fig. 11).

To illustrate the diversity and intensity, we present the highlights of 2014 as an example. There were two appearances on radio and television, 28 interviews and articles in the press, a debate with a large presence in the city council of a provincial capital and a symposium of the Royal Netherlands Academy of Sciences. Two major national newspapers dedicated substantial articles to the cisgenic late blight resistant potato, and the day open to the public was widely announced and received over 30 exposures in the media. There were 15 presentations in meetings, posters and workshops, and a YouTube film was made for the German I/Bio organisation (http://youtu. be/veX6VXAfUoU). Six key notes were delivered at international conferences such as at meetings of the EAPR and PAA. There were international contacts with Cornell University, the International Potato Center, the research institution TEAGASC in Ireland and the University of Würzburg (Germany). The EU-AMIGA project in which DuRPh participates received press coverage in the Washington Post and the MIT Technological Review. By invitation, a presentation was given at a webinar on genetically engineered disease resistance in crops, organised by the US National Academy of Science found at http://nas-sites.org/ge-crops/2014/09/22/webinar-november-6/. Two contributions were given at seminars for teachers at colleges in the Netherlands and one at the British CommNet for Education, entitled 'Learn about opportunities and

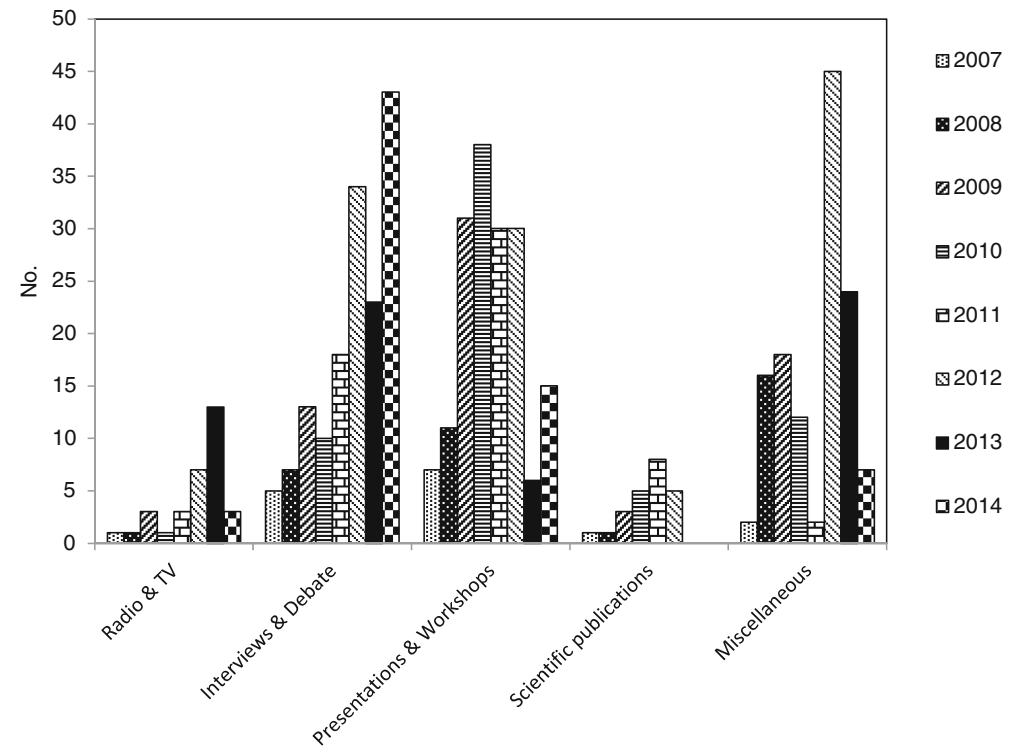

Fig. 11 Number of appearances of DuRPh in media and events in 2007 through 2014 
challenges for using genetically modified crops for sustainable agriculture: the potato case'.

The contribution of the DuRPh project to the public debate and some impact can be summarised as follows. Policy views regarding 'innovative techniques in plant breeding' in the Netherlands can be traced back largely to the concrete DuRPh case. The project showed a concrete application which makes the benefits for sustainability less hypothetical (Lotz et al. 2014). The content of DuRPh-genotypes that need less spraying, cisgenesis with potato genes only and resistance management-received more and more attention in the media, and genetic modification itself moved to the background, although it remained a topic. Environmental groups reacted in various ways, ranging from positive criticism - mostly referring to the beneficial effects on the environment - to various types of negative feedback. A number of groups indicated that the DuRPh programme produced a well-documented case which is suitable as an input for a constructive discussion on the use of cisgenesis in potato breeding. The DuRPh project proved that in the Netherlands, field trials with GM plants with minimal protection-just provided with a sign 'no trespassing'-largely go undisturbed. A demonstration field was laid down and visited by hundreds of interested citizens with all kinds of background and observed with keen interest without any disturbance.

\section{Potential of Deployment of $\boldsymbol{R}$ Genes for Global Food Security Through Breeding or GM}

Currently, more potatoes are produced in developing countries as they were termed in the 1960s than in developed countries. Now, it is the third food crop for human consumption after wheat and rice. Especially in China, India and Sub-Saharan Africa, production continues to increase fast. The total production in developing countries is now close to 250 million tons, up from 35 million tons in 1960 (FAOSTAT 2014). The cost of late blight — control and losses — has been estimated at about $\$ 4$ billion by Judelson and Blanco (2005) and Haldar et al. (2006) and at around $€ 9$ billion by Haverkort et al. (2009). For this reason, many initiatives in developing countries gave and give attention to the disease (Forbes 2010). Examples are PICTIPAPA (International Cooperative Program for Potato) in the Toluca Valley in Mexico, the Global Initiative on Late Blight (GILB) which was launched in 1996 as an ad hoc group of scientists that organised several meetings such as the one at Beijing (http://gilb.cip.cgiar.org/) and EuroBlight, a network in Europe that maintains a website on control and has a database describing over 25,000 isolates of $P$. infestans sampled in Europe (see http://www.euroblight.net/EuroBlight.asp for one of the proceedings). LatinBlight started in 2014, and AsiaBlight is being discussed. There are the APSPII which is the Agricultural Biotechnology Support Project (http:/www.absp2.cornell. edu/projects/project.cfm?productid=4) of Cornell University and an initiative formalised by a letter of intent signed by CIP, Cornell University and Wageningen UR to cooperate when it comes to cisgenic late blight resistance. A FAO-CIP project leads to an improvement of the farmer field school approach and a number of networks such as PRAPACE in Sub-Saharan Africa and similar ones in Asia and Latin America. All these initiatives supported the considerable increase in production in developing countries. 
In large parts of China and Africa, the crop is mainly rain fed and often grown in two seasons associated with either two rainy seasons or with a single long rainy season, the monsoon. According to A.J. Haverkort (personal observations), growers tend to avoid having a fully grown crop at the height of the rainy season as this is the most favourable weather for the development of late blight and control is hardly possible as fungicides are washed off when it rains daily with heavy intensity. Where two rainy seasons occur, such as is the case close to the equator, farmers usually plant a crop two times per year at the peak of each rainy season. After emergence, rainfall generally diminishes and the crop continues to grow on residual soil moisture. Where there is only one rainy season at greater latitudes, farmers may have two potato crops as well: firstly, a minor premonsoon crop which is planted when the first rains appear and harvested at the height of the rainy season, when the canopy is dead due to late blight. The second and most important crop is planted when the rains gradually subside and the canopy dies due to lack of water. It is clear that growers trade off the risks of blight with that of drought. Blight cannot be controlled when rains are too heavy, and crops cannot be irrigated where no irrigation water is available in regions with slopes. Examples of yield losses due to late blight reported in selected countries are in Romania ( $6 \%$ up to $40 \%$; Cupsa et al. 1983), Poland (22.8\%; Pietkiewicz 1991), Burundi (up to 40\%; Higiro and Danial 1994), India (38\% up to 65\%; Rao and Veeresh 1989), Cameroon (25-75\%; Fontem and Aighewi 1993), Kenya (23-81\%; Lungaho et al. 2008) and China (5-60\%; Xie and Wang 2001). Based on these data, we can safely assume that average yield losses due to late blight are $35 \%$, meaning that the 225 million tons currently produced in developing countries could have been 78.8 million tons more with optimal control of blight. At a value of $€ 100$ per ton, this represents a farm gate value of $€ 7.9$ billion. This figure does not take into account yield losses from drought where growers on purpose miss the peak of the rainy season. It is estimated (Haverkort et al. 2009) that in developed countries where chemical late blight control is more or less adequate, the costs of control are about $10 \%$ of the production cost. Of the 150 million tons produced, there at $€ 100$ per ton and $10 \%$ represents $€ 1.5$ billion. Taking the figures from the developing and developed countries together, the estimated total costs and losses of the blight disease are close to $€ 9.4$ billion per year. Other approximations may yield different figures, but it is clear that the bulk of the losses are suffered in developing countries where food security is an issue. It is in such countries that late blight resistance will have the highest impact on crop profitability, on the livelihood of farmers and on food security of its population.

With the annual global economic losses estimated to be more than $€ 9$ billion per annum, the potential costs of the potential solution - insertion of $R$ genes with selection markers or cisgenic — seem insignificant. The DuRPh project's budget is $€ 1$ million per annum which allows for the cloning, transformation, selection, resistance management and communication. Some $80 \%$ of these funds were used for research and development. With each new $R$ gene detected and found not to be homologous with $R$ genes found earlier on, the chance decreases to detect new $R$ genes and, at some point in the future, the pool from which to create different $R$ gene stacks will be more or less completed. So, in order to implement the DuRPh strategy, only transformation of available $R$ gene stacks to existing varieties, followed by selection of the proper trueto-type genotypes expressing resistance, needs to be performed. We estimate this to be valued at between $€ 250,000$ to $€ 500,000$ per variety exempted from GM regulation 
with a $100 \%$ success rate of resistance expression and market acceptability. This then needs to be backed up by a late blight monitoring-based resistance management system. For the Netherlands, three monitoring field plots might suffice. Laying out three of such monitoring plots, sampling and analysing $P$. infestans costs around $€ 100,000$ per annum. In contrast, breeding an entirely new variety is estimated to cost at least $€ 1$ million starting from a series of crosses yielding some 100,000 seedlings which have to be actively discarded for about 11 years to yield one variety. Even then it is still most uncertain if this particular variety will prove itself in the market, only $10 \%$ of the thus created varieties become successful, i.e. more than 10 ha seed grown annually. Wageningen University and Research Centre currently is not attempting to introduce the DuRPh strategy of gene stacking, true-to-typing and disease monitoring in developing countries as it is preferred to do so once the cisgenic approach is considered a low risk-comparable to conventional breeding by legislators in the European Union.

\section{Final Deliberations}

Potential advantages of cisgenesis are that it may be better perceived by consumers than products obtained by transgenesis. There is also a chance that they need not go through the risk assessment and the regulatory framework of GM crops if legislators deregulate this type of genetic modification as they have done in the European Union with mutagenesis for instance.

Cisgenesis, however, has some limitations as it only uses genes from the Solanum pool that contains crossable species. So, resistance genes from not crossable species such as from Solanum nigrum or Solanum dulcamara are not usable. Not all $R$ genes are active in all varieties, so the deployment is variety dependent. Moreover, certain varieties transform easily whereas others with difficulty only as shown by a low transformation efficiency. A limitation of cisgenesis compared to transgenesis where the use of a selectable marker such as kanamycin is common is that it is very expensive. Mass transformation in the cisgenic approach and verification through PCR is far more expensive per event - about 15 times more costly - than with the use of a selectable marker gene. Compared to conventional breeding methods, the cisgenic, but also the transgenic, approach has the disadvantage that it is a genetic modification approach meeting public apprehension. Finally, conventional breeding yields varieties - especially in organic breeding programmes - that not only differ in late blight resistance but may also have been selected for other resistances such as against early blight, black scurf and nematodes. Especially early blight may become a greater problem as it is also partly controlled by chemical late blight control. By upgrading old varieties, the cisgenic approach also sustains the longevity of such varieties and possibly of some unwanted quality weaknesses.

Between 1995 and 2000, potatoes with resistance to Colorado beetle (Leptinotarsa decemlineata), potato leafroll virus (PLRV) and potato virus Y (PVY) were registered and allowed in the USA. NewLeaf for instance was a Russet Burbank supplied with a Bacillus thuringiensis $(B t)$ gene by Monsanto that made the crop resistant to the Colorado beetle (Grafius and Douches 2008). Producers withdrew these improved varieties from the market because the industry was afraid of mixing GM potatoes with conventional ones and thereby losing markets such as the Japanese. Assuring non- 
mixtures adds costs without any benefits (Thornton 2003). Similar developments such as potatoes resistant to potato tuber moth with $B t$ genes, extensively tested in Egypt and South Africa, were stopped for similar reasons beside the fear of excessive costs of regulatory compliance of GM potatoes.

The DuRPh project aimed at developing a proof of principle to arrive at durable resistance to late blight. The objective of the government for funding was to develop a case since in the Netherlands, no example - neither public nor private - existed of a crop being genetically modified. The case was intended to keep the public research up to date and internationally competitive and to have an example to foster a discussion on a major societal dilemma. Abundant pesticide use- $-50 \%$ of all fungicides applied in the Netherlands are used against blight — versus almost no use followed resistance via genetic modification. In addition, the result might assist in keeping a competitive edge in the Netherlands' seed potato variety development, seed production and trade industry. Meanwhile, in Europe, two private attempts were undertaken. The company BASF developed the variety Amflora, also known as EH92-527-1. This along with the starch varieties Modena (AV43-6-G7) and Amadea (AM 04-1020) that through genetic modification with RNA interference (RNAi) of the GBSS gene only produced amylopectin and no amylose. It took the company 13 years before the EU granted admission for cultivation in 2010. The second example, also produced by BASF, is the variety Fortuna derived from the variety Fontane to which two late blight $R$ genes, Rpi-blbl and Rpi-blb2, were introduced through genetic modification. The $S$. bulbocastanum genes were under control of their native promoter and terminator. The two $R$ genes were transferred into Fontane with $A$. tumefaciens with the transgenic antibiotic imidazolone resistance gene as a selectable marker (Storck et al. 2012). In 2011, the company announced that it was seeking admission of Fortuna to the European market, only to announce 2 years later that it would end its GM activities in Europe following uncertainties of European regulation and legislation and threats of destruction of experimental plots. Moreover, it was not possible for the company to find seed potato growers in the Netherlands as these farmers could then not find a market for their conventional potatoes because their customers were afraid of mixtures of non-GM with GM.

Meanwhile, in the USA, new developments are shown by the Simplot Company that knock down genes in the established frying variety Russet Burbank through RNAi. The targeted genes are polyphenol oxidase responsible for blue discoloration of tubers after bruising. Also the knock-down of the enzyme responsible for the accumulation of asparagine was targeted that together with the reducing sugars glucose and fructose in the Maillard reaction causes undesired browning and acrylamide accumulation of fried potato products. The US Food and Drug Administration admitted this product, called 'innate' by Simplot for the US market. Future innate potatoes will also be supplied with the Rpi-vnt1.1 gene to make the crop resistant to late blight. To date, it is too early to report on consumer acceptance regarding these GM potato genotypes that, for the first time, have direct consumer benefits, namely less discoloration and less or no formation of acrylamide.

Beside food safety, societal concern is also about patenting, breeders' rights and the concentration of intellectual property with only a few companies. This reduces competition which potentially leads to monopoly and dependence of growers and consumers from a few suppliers. Some of the genes used in the DuRPh project are patented 
or patent pending; i.e. protection has been asked for the use of these $R$ genes in existing varieties in different countries. So, Wageningen UR can decide at what price and who can use them. Restrictions such as mandatory monitoring and changing stack composition can be imposed if the blight population threatens the current resistance genes. Patenting also allows granting humanitarian use licences for developing countries. If cisgenesis would be deregulated by the EU, like some other GM techniques such as mutation induction and protoplast fusion between crossable species, then the relatively small Netherlands' potato breeding companies can use the technique without risking a civil society and consumer organisation hostile campaign which can spill over to other products as well as the costs and complexities associated with the procedure to register and manage cisgenic varieties. Already a commercial exploitation consortium has been set up that jointly funds cisgenic late blight resistance research. The group is not exclusive, and genes will not be supplied exclusively to certain users but nonexclusive as to assure wide future deployment without hindrance from monopolies.

Finally, all the knowledge and lessons learnt about the different $R$ genes, their chromosomal location, their specificity, the background dependence, the maximum size of a stack, its regeneration time and associated somaclonal variation frequency and its stability is being used in various programmes both within academia as well as with potato breeding companies. The DuRPh and other projects at Wageningen UR Plant Breeding yield information about the $R$ genes and their performance in various genetic backgrounds that conventional commercial breeding companies will use straightforward. Cisgenic transformation of varieties or breeding lines with constructs containing desired genes not present yet in advanced potato gene pool material is offering classical breeding a head start using these GM plants as parents in crosses. Then, less backcrosses with $S$. tuberosum are needed. Especially the use of multiple gene constructs can gain decades as it also embodies a Mendelian 1:1 segregation of clustered $R$ genes. It is expected that the DuRPh project has set good scientific bases of future resistance management of late blight disease by engineering potato varieties with $R$ gene stacks in the Netherlands and other parts of the world.

Acknowledgements The DuRPh research was funded by the Netherlands Government by the 'Fonds voor Economische Structuurversterking (FES)'.

\section{References}

Anonymus (2013) Landbouweconomisch Bericht. Berkhout, Silvis PH, en Terluin (eds.) LEI-rapport 2013041ISNN0169-3255, 212 pp

Black W, Mastenbroek C, Mills WR, Peterson LC (1953) A proposal for an international nomenclature of races of Phytophthora infestans and of genes controlling immunity in Solanum demissum derivates. Euphytica 2:173-240

Cooke DEL, Cano LM, Raffaele S, Bain RA, Cooke LR et al. (2012) Genome analyses of an aggressive and invasive lineage of the Irish potato famine pathogen. PLoS Pathog 8(10):e1002940. doi:10.1371/journal. ppat. 1002940

Cupsa I, Ignatescu I, Vogel E (1983) An epidemic of potato late blight in 1982, and measures taken to prevent it in 1983 (Epidemia de mana a cartofului in anul 1982 si masuri de prevenire a acesteia in anul 1983). Productia Vegetala Horticultura 32:22-26 
De Vetten N, Wolters MA, Raemakers K, van der Meer I, ter Stege R, Heeres P, Visser RGF (2003) A transformation method for obtaining marker-free plants of a cross-pollinating and vegetatively propagated crop. Nat Biotechnol 21:439-442

Fry WE (1977) Integrated control of potato late blight: effects of polygenic resistance and techniques of timing fungicide applications. Phytopathology 67:415-420

FAOSTAT 2014, http://faostat.fao.org/default.aspx. Accessed August 2015

Flier WG, Kroon LPNM, Hermansen A, Van Raaij HMG, Speiser B, Tamm L, Fuchs JG, Lambion J, Razzaghian J, Andrivon D, Wilcockson S, Leifert C (2007) Genetic structure and pathogenicity of populations of Phytophthora infestans from organic potato crops in France, Norway, Switzerland and the United Kingdom. Plant Pathol 56:562-572

Flier WG, Turkensteen LJ (1999) Foliar aggressiveness of Phytophthora infestans in three potato growing regions in the Netherlands. Eur J Plant Pathol 105(4):381-388

Fontem DA, Aighewi B (1993) Effect of fungicides on late blight control and yield loss of potato in the western highlands of Cameroon. Int J Pest Manag 39:152-155

Forbes G (2010) Late blight, action plan for an effective response to a global threat. White Paper June http:// 192.156.137.121:8080/cipotato/publications/pdf/222222.pdf

Grafius EJ, Douches DS (2008) The present and future role of insect-resistant genetically modified potato varieties. In: Romeis J, Shelton AM, Kennedy GG (eds.) Integration of insect-resistant genetically modified crops within IPM programs. pp. 195-205

Haas BJ, Kamoun S, Zody MC, Jiang RH, Handsaker RE, Cano LM, Grabherr M, Kodira CD, Raffaele S, Torto-Alalibo T, Bozkurt TO, Ah-Fong AM, Alvarado L, Anderson VL, Armstrong MR, Avrova A, Baxter L, Beynon J, Boevink PC, Bollmann SR, Bos JI, Bulone V, Cai G, Cakir C, Carrington JC, Chawner M, Conti L, Costanzo S, Ewan R, Fahlgren N, Fischbach MA, Fugelstad J, Gilroy EM, Gnerre S, Green PJ, Grenville-Briggs LJ, Griffith J, Grünwald NJ, Horn K, Horner NR, Hu CH, Huitema E, Jeong DH, Jones AM, Jones JD, Jones RW, Karlsson EK, Kunjeti SG, Lamour K, Liu Z, Ma L, Maclean D, Chibucos MC, McDonald H, McWalters J, Meijer HJ, Morgan W, Morris PF, Munro CA, O’Neill K, Ospina-Giraldo M, Pinzón A, Pritchard L, Ramsahoye B, Ren Q, Restrepo S, Roy S, Sadanandom A, Savidor A, Schornack S, Schwartz DC, Schumann UD, Schwessinger B, Seyer L, Sharpe T, Silvar C, Song J, Studholme DJ, Sykes S, Thines M, van de Vondervoort PJ, Phuntumart V, Wawra S, Weide R, Win J, Young C, Zhou S, Fry W, Meyers BC, van West P, Ristaino J, Govers F, Birch PR, Whisson SC, Judelson HS, Nusbaum C (2009) Genome sequence and analysis of the Irish potato famine pathogen Phytophthora infestans. Nature 461(7262):393-398

Haesaert G, Vossen JH, Custers R, De Loose M, Haverkort AJ, Heremans B, Hutten R, Kessel G, Landschoot S, Van Droogenbroeck B, Visser RGF, Gheysen G (2015) Field performance of an established potato variety improved by transformation with multiple late blight resistance genes. Crop Prot 77:163-175

Haldar K, Kamoun S, Hiller NL, Bhattacharje S, van Ooij C (2006) Common infection strategies of pathogenic eukaryotes. Nat Rev Microbiol 4:922-931

Haverkort AJ, Hillier JG (2011) Cool farm tool - potato: model description and performance of four production systems. Potato Res 54:355-369

Haverkort AJ, Boonekamp PM, Hutten R, Jacobsen E, Lotz LAP, Kessel GJT, Visser RGF, van der Vossen AEG (2008) Societal costs of late blight in potato and prospects of durable resistance through cisgenic modification. Potato Res 51:47-57

Haverkort AJ, Struik PC, Visser RGF, Jacobsen E (2009) Applied biotechnology to combat late blight in potato caused by Phytophthora infestans. Potato Res 52:249-264

Higiro J, Danial DL (1994) Potato production in Burundi: constraints and research. In: Proceedings of a regional workshop for Eastern, Central and Southern Africa. Proceedings of a regional workshop for Eastern, Central and Southern Africa, Njoro, Kenya. pp. 117-118

James C (2014) Global status of commercialized biotech/GM crops: 2014. ISAAA Brief No. 49. ISAAA: Ithaca, NY, $325 \mathrm{pp}$

Jo KR, Arens M, Kim TY, Jongsma MA, Visser RGF, Jacobsen E, Vossen JH (2011) Mapping of the $S$. demissum late blight resistance gene $R 8$ to a new locus on chromosome IX. Theor Appl Genet 123:13311340

Jo K-R (2013) Unveiling and deploying durability of late blight resistance in potato from natural stacking to cisgenic stacking. PhD Thesis, Wageningen University, Wageningen, The Netherlands, p 168

Jo KR, Kim CJ, Kim SJ, Kim TJ, Bergervoet-van Deelen JEM, Jongsma MA, Visser RGF, Jacobsen E, Vossen J (2014) Development of late blight resistant potatoes by cisgenic stacking. BMC Biotechnol 14: $1472-6750$ 
Jo KR, Visser RGF, Jacobsen E, Vossen JH (2015) Characterisation of the late blight resistance in potato differential MaR9 reveals a qualitative resistance gene, R9a, residing in a cluster of Tm-2 2 homologs on chromosome IX. Theor Appl Genet 128(5):931-941

Jo K-R, Zhu S, Bai Y, Hutten RCB, Kessel GJT, Vleeshouwers VGAA, Jacobsen E, Visser RGF, Vossen JH (2016) Plant pathogen resistance biotechnology. In: Collinge DB (ed) Wiley-Blackwell. pp. 448

Judelson HS, Blanco F (2005) The spores of Phytophthora weapons of the plant destroyer. Nat Rev Microbiol 3:47-57

Jupe F, Witek K, Verweij W, Śliwka J, Pritchard L, Etherington GJ, Maclean D, Cock PJ, Leggett RM, Bryan GJ, Cardle L, Hein I, Jones JDG (2013) Resistance gene enrichment sequencing (RenSeq) enables reannotation of the NB-LRR gene family from sequenced plant genomes and rapid mapping of resistance loci in segregating populations. The Plant Journal 76(3):530-544

Kim HJ, Lee HR, Jo KR, Mahdi Mortazavian SM, Huigen DJ, Evenhuis B, Kessel G, Visser RGF, Jacobsen $\mathrm{E}$, Vossen JH (2012) Broad spectrum late blight resistance in potato differential set plants MaR8 and $\mathrm{Ma} R 9$ is conferred by multiple stacked $R$ genes. Theor Appl Genet 124:923-935

Lalancette N, Ellis MA, Madden LV (1988) Development of an infection efficiency model for Plasmopara viticola on American grape based on temperature and duration of leaf wetness. Phytopathology 78:794 800

Li G, Huang S, Guo X, Li Y, Yang Y, Guo Z, Kuang H, Rietman H, Bergervoet M, Vleeshouwers VGAA, van der Vossen E, Qu D, Visser RGA, Jacobsen E, Vossen JH (2011) Cloning and characterization of $R 3 b$; members of the $R 3$ superfamily of late blight resistance genes show sequence and functional divergence. Mol Plant Microbe Interact 24:1132-1142

Lotz LAP, Van de Wiel CCM, Smulders MJM (2014) GM crops and sustainable agriculture: a proposed way forward in the societal debate. NJAS Wageningen J Life Sci 70-71:95-98

Lungaho C, Nyongesa N, Lemaga B (2008) Yield and economic losses caused by potato late blight in Central Kenya. https://research.cip.cgiar.org/confluence/download/attachments/8159378/p20.pdf

Nærstad R, Hermansen A, Bjor T (2007) Exploiting host resistance to reduce the use of fungicides to control potato late blight. Plant Pathol 56:15-166

Pietkiewicz JB (1991) Potato production and protection in Poland in the 1990s. Bull-OEPP 21:1-7

The Potato Genome Sequencing Consortium (2011) Genome sequence and analysis of the tuber crop potato. Nature 475:189-195

Rao ANS, Veeresh GK (1989) Estimation of yield loss due to late blight in rainfed potato. Curr Res. University of Agricultural Sciences, Bangalore, 18:157-158

Rietman H, Bijsterbosch G, Cano LM, Lee HR, Vossen JH, Jacobsen E, Visser RGF, Kamoun S, Vleeshouwers VGGA (2012) Qualitative and quantitative late blight resistance in the potato variety Sarpo Mira is determined by the perception of five distinct RXLR effectors. Mol Plant-Microbe Interact 25:910-919

Rodewald J, Trognitz B (2013) Solanum resistance genes against Phytophthora infestans and their corresponding avirulence genes. Mol Plant Pathol 14(7):740-757

Schouten HJ, Krens FA, Jacobsen E (2006) Cisgenic plants are similar to traditionally bred plants: international regulations for genetically modified organisms should be altered to exempt cisgenesis. EMBO Reports 7:750-753

Skelsey P, Rossing WA, Kessel GJT, van der Werf W (2010) Invasion of Phytophthora infestans at the landscape level: how do spatial scale and weather modulate the consequences of spatial heterogeneity in host resistance? Phytopathology 100:1146-1161

Skelsey P, Rossing WAH, Kessel GJT, Powell J, van der Werf W (2005) Influence of host diversity on development of epidemics: an evaluation and elaboration of mixture theory. Phytopathology 95:328-338

Storck T, Böhme T, Schultheiss H (2012) Status and perspectives of GM approaches to fight late blight. Thirteenth EuroBlight workshop, St. Petersburg (Russia), 9-12 October 2011, PPO-Special Report 15: $45-48$

Taylor J (1973) The analysis of designed experiments with censored observations. Biometrics 29:35-43

Thornton M (2003) The rise and fall of NewLeaf potatoes. NABC Report 15: Biotechnology: Science and Society at a Crossroad, pp. 235-243

Vleeshouwers VGAA, Raffaele S, Vossen JH, Champouret N, Oliva R, Segretin ME, Rietman H, Cano LM, Lokossou AA, Kessel GJT, Pel M, Kamoun S (2011) Understanding and exploiting late blight resistance in the age of effectors. Annu Rev Plant Physiol Plant Mol Biol 49:507-531

Vossen JH, Dezhsetan S, Esselink D, Arens M, Sanz MJ, Verweij W, Verzaux E, van der Linden CG (2013) Novel applications of motif-directed profiling to identify disease resistance genes in plants. BMC Plant Methods 9:37-49 
Vossen JH, Nijenhuis M, Arens-de Reuver MJB, van der Vossen EAG, Jacobsen J, Visser RGF (2011). Cloning and exploitation of a functional $R$ gene from Solanum chacoense. Patent number WO/2011/ 034433

Wang M, Sjefke A, van den Berg RG, Vleeshouwers VGAA, van der Vossen EAG, Vosman B (2008) Allele mining in Solanum: conserved homologues of Rpi-blb1 are identified in Solanum stoloniferum. Theor Appl Genet 116(7):933-943

Xie K, Wang Y (2001) CIP potato late blight research in China. Journal of Agricultural University of Hebei. 8 pp https://research.cip.cgiar.org/confluence/download/attachments/37192022/xiekaiyun_10_pdf? version=1\&modificationDate $=1273631094000$. Accessed August 2015

Zhu S, Duwal A, Su Q, Vossen JH, Visser RGF, Jacobsen E (2013) Vector integration in triple R gene transformants and the clustered inheritance of resistance against potato late blight. Transgenic Res 22(2): 315-325

Zhu S, Vossen JH, Bergervoet M, Nijenhuis M, Kodde L, Kessel GJT, Vleeshouwers V, Visser RGF, Jacobsen E (2015) An updated conventional- and a novel GM potato late blight $R$ gene differential set for virulence monitoring of Phytophthora infestans. Euphytica 202(2):219-234 